\title{
THE IMPACT OF COMMERCIAL RAINFALL INDEX INSURANCE: EXPERIMENTAL EVIDENCE FROM ETHIOPIA
}

\author{
Shukri Ahmed \\ Food and Agriculture Organization of the United Nations, Rome, Italy \\ Craig McIntosh* \\ University of California, San Diego, USA \\ Alexandros Sarris \\ National and Kapodistrian University of Athens, Greece
}

August 2017

\begin{abstract}
We present the results of an experiment introducing commercial rainfall index insurance into drought-plagued farming cooperatives in Amhara State, Ethiopia. We introduce a market-priced rainfall deficit insurance product through producer cooperatives, and test a number of potential ways to kick-start private demand. Takeup of the insurance at market prices is very low, between $.5 \%$ and $3 \%$ across seasons, but a low-cost promotion at baseline increases willingness to pay for multiple seasons. When we use a randomized experiment to distribute small free insurance contracts to farmers, $39 \%$ of subsidized individuals enroll but this fails to stimulate input use, yields, or income, and nor does it enhance demand in subsequent seasons. Our experience in interlinking credit with insurance shows that while serious logistical challenges need to be overcome, real demand can exist for state-contingent credit in this context.
\end{abstract}

Keywords: Index Insurance, Randomized Experiments, Ethiopian Agriculture

JEL Codes: O13, G22, C93

*Corresponding author, School of Global Policy and Strategy, UCSD. 9500 Gilman Dr., La Jolla CA 92093-0519, ctmcintosh@ucsd.edu. We are grateful to BASIS/USAID and to the Agricultural Technology Adoption Initiative for funding this project, and the Ethiopian Economics Association for their survey work. We thank Rene Gommes for help on agrometeorology and index development, Michael Carter, Ethan Ligon, and Elisabeth Sadoulet for useful comments, and Alex Botsis, Maya Duru, Fotis Papadapoulis, Alixa Sharkey, and Diego Vera-Cossio for excellent research assistanceship with the project. The project received research clearance under UCSD IRB \#101578. 


\section{INTRODUCTION}

Smallholder farmers are beset by an interlocking set of market failures, and when credit and insurance markets are missing, farmers can become trapped in a low-investment equilibrium (Rosenzweig \& Binswanger 1993). Production risk likely hampers farmers' adoption of higher yielding technologies (Dercon, 2005), particularly when these shocks are covariate (Townsend, 1994, Conning and Udry, 2007). Risk-driven reluctance to invest in inputs such as fertilizer and improved seeds may be largely responsible for the fact that Africa has not undergone a 'green revolution' (Skees and Collier 2007). This theoretical insight, combined with the lack of moral hazard in weather variation and the relative availability of rainfall and other meteorological data for developing countries (e.g. satellite based $\mathrm{NDVI}^{1}$ ), makes weather index insurance (WII) a potentially promising welfare-enhancing intervention. These products allow the agricultural production system to shift who bears weather risk by transferring its burden off of local producers and towards globally diversified reinsurers. If producers are 'risk rationed' in their use of credit (Boucher et al. 2008), then lifting weather risk from their shoulders can crowd in demand for input investment, and holds the promise of generating first-order increases in average productivity. Several recent studies have shown dramatic effects of index insurance on producer

behavior when these products are provided at subsidized prices (e.g., Mobarak and Rosenzweig 2013, Karlan et al., 2014, and Elabed and Carter 2014, Cai et al. 2016).

Despite this promising picture, standalone weather index insurance (namely not linked to any other products) has struggled as a commercial product (JPAL, 2016). The core reason for this has been lack of demand at market prices (Cole et al 2013, Gine \& Yang 2009). Index insurance is partial insurance; even standard demand theory makes equivocal predictions about the relationship between parameters such as risk aversion or background risk and the demand for partial insurance. The possibility that the index may fail to pay out in some loss states means that the purchase of index insurance can increase the variance of income (Clarke, 2016). Crops are subject to multi-peril risks but complex indexes may be likely to generate behavioral barriers to demand such as ambiguity aversion (Bryan 2010), failure to reduce compound lotteries (Elabed and Carter 2015), and non-linear responses to probabilities (McIntosh et al. 2016). Relative to credit, further, insurance turns the tables of trust of between firm and client, requiring that the

\footnotetext{
${ }^{1}$ NDVI stands for Normalized Difference Vegetation Index
} 
client initially place confidence in the future actions of the firm rather than vice versa. Selling insurance requires a trusted brand, and moving to scale requires a partner who has the capacity to serve more than a pilot clientele. The index must be clearly correlated with yields in the minds of customers for them to see the value in what is effectively a derivative rather than proper indemnity insurance. Further, weather index insurance products have proven difficult to field in the developing world due to their technical complexity and requirements for long historical data on which to build the index. In short, many obstacles exist to launching unsubsidized WII products in developing countries.

This project set out to build a private-sector driven rainfall index insurance product linked with seasonal credit and to field it among drought-exposed farmers in Amhara State, Ethiopia. It aimed to address the credibility problem by working with the largest private insurance company (Nyala Insurance CO or NISCO) and the largest private lender (Dashen Bank) in the country. We collaborated with our partners to identify market-friendly, drought-exposed villages, with potential for increased productivity, and to take advantage of Ethiopia's strong cooperative system to market and implement the standalone and the interlinked insurance-credit products. The product was designed to cover the cost of purchased inputs to farming, namely fertilizers and improved seeds. Smallholder rainfed Ethiopian agriculture is one of the most weather-exposed farming systems on earth, and we further selected the villages studied here to have directly reported deficit rainfall as the primary source of risk in their location. We conducted four rounds of panel surveys and three years of weather index insurance sales (Table 1). To understand the price dimension, we randomized insurance premium subsidy vouchers at the farmer level, rerandomizing each year so as to understand the dynamic demand effects of subsidies.

The Ethiopian context is an ideal one in which to pilot index insurance from the perspective of exposure to risk, and several recent studies have been conducted in the country (e.g. Hill and Viceisza 2010; Berhane et. al. 2014; Dercon, et. al. 2014; Oxfam's HARITA project described in OXFAM 2014; and McIntosh et al. 2016). However, from the institutional perspective Ethiopia is a very challenging environment in which to introduce a novel and complex private-sector financial service. Rigidity of input supply chains, strong government-led approach to both credit and fertilizers, and the presence of the massive Productive Safety Nets Program (PSNP) in Amhara province all reinforce the central role that the government plays in 
agriculture and risk management. There is no private ownership of land in Ethiopia, and consequently land is not available as a source of collateral. This has driven a corresponding absence of private-sector credit in the rural sector. The high climate variability and its central role in driving risks in Ethiopian agriculture makes reinsurers reluctant to provide coverage, and increases the price of reinsurance. Under the current system the financial drought risk is covered by the PSNP and other related programs and they are managed by the State governments, who also must provide loan guarantees for all publicly-backed credit moving through the state input financing system. ${ }^{2}$ All of this implies that the public sector (particularly state government) plays a driving role in absorbing agricultural risk, and while these entities may be eager to spread these risks more broadly it may be a challenging context in which to engineer private-sector institutional means to do so.The study design featured both a standalone WII product as well a product that interlinked insurance with credit, providing a completely new source of privatesector loans to farmers if they were willing to purchase insurance policies for which the bank would be the beneficiary. This provides access to a type of state-contingent credit that need only be repaid if the rainfall realization is good. Several recent studies have found that bundling insurance with a credit contract actually decreases demand for fertilizer relative to a standalone credit product (Giné and Yang, 2009, Banerjee et. al. 2014); Our study takes this logic from the opposite direction and says that if both credit and insurance markets have failed, insurance can play a critical role in crowding in credit supply by protecting the lender (Carter et al. 2016). In the end we were not able to field the interlinked product in a full experimental way, but we describe the product and its obstacles, and present promising descriptive evidence from the cooperative that did implement the product and issued hundreds of interlinked loans. In analyzing an experiment that overlays external subsidies on a market-driven product, it is useful to distinguish three successive justifications for the welfare benefits of WII. First, if a commercially priced product faces sufficient demand, then a sustainable market can be built without subsidies and we can expect the private market to deliver the welfare benefits of risk protection. A second justification would be that initial subsidies could be used to kick-start a private market, and so an initial up-front investment could eventually set up a sustainable institution. ${ }^{3}$ Finally, as argued

\footnotetext{
${ }^{2}$ Productive Safety Net Program (PSNP) is a national program, started in 2005, that helps vulnerable families to ensure minimum nutrition.

${ }^{3}$ As has been the case with microfinance (Morduch 1999, Mersland and Strøm, 2010).
} 
in Karlan et al. (2014), it may be the case that pure transfers provided in the form of risk subsidies may unlock a willingness to invest in higher-risk, higher-yield technologies that increase income in a first-order sense. In this case, rather than making a simple cash transfer or subsidizing inputs, we might prefer to provide transfers in a state-contingent form by providing free index insurance. By independently randomizing individual subsidies over the top of a commercially priced product across multiple seasons, we are able to examine the validity of each of these three justifications in our setting.

Unfortunately, our results do not provide support for any of the potential justifications for index insurance, at least as developed and marketed in this context. First, unsubsidized demand is low. Uptake rates at commercial prices ( $130 \%$ of actuarially fair) is roughly a half of a percent over the course of the study. No combination of interventions achieved enough private demand to make the product commercially viable in the first few years. More than a third of individuals who are offered a voucher for a small free policy enroll in the insurance, but they typically insure only up to the amount of the voucher, and the vouchers have no dynamic benefits for demand. While individuals who were risk rationed at baseline are more likely to take up insurance when offered a voucher, and invest less overall in inputs, there is no differential impact of the treatment on the risk rationed. Voucher subsidies providing a small free insurance policy generated a large number of enrollments, while voucher subsidies presented as cash-equivalent reductions in the market price relative to fully insuring all of one's land did not.

Further, receipt of this form of state-contingent cash transfer (which should lessen the overall risk exposure of the household) did not lead to a measurable improvement in input use, agricultural yields, or household income. This result stands in contrast to Karlan et al. (2014), who find free insurance policies to have strongly significant effects, and indeed effects that are two orders of magnitude larger than an equivalent transfer in the form of an input subsidy. Why such divergent results? We investigate several potential explanations. First, we provided only relatively small insurance subsidies to farmers (average premium voucher value of $\$ 20$, maximum payout implied of \$80). While we were trying to provide input insurance not yield insurance, and hence quantities and subsidies are both small, we have an almost perfect ability to predict the sum insured with the voucher amount, and even when we examine the slope effect or the impact at high voucher amounts, there is no indication of an input use response. Second, 
could it be that people just didn't understand the insurance? We use a survey of comprehension in the fourth round to examine this, and find that indeed understanding of the product was very imperfect, and a promotion conducted at baseline to improve uptake had a substantial effect on willingness to purchase insurance. Finally, we discuss contextual features that may have caused the product to struggle in Ethiopia in particular, including rigid state-dominated supply chains and pre-existing risk spreading institutions.

Overall, our results demonstrate several specific dimensions in which private-sector standalone index insurance is an uphill market to create. Demand in the absence of subsidies was too low to sustain a market, and neither the dynamic nor the productivity-based arguments for subsidies find support in our data. However, the results in a limited context with interlinked contracts are encouraging, suggesting that the emphasis until now on standalone weather index insurance has been misplaced and the thrust of future research should be on testing interlinked insurance-loan products.

The paper is organized as follows: Section 2 describes the setting for the study, Section 3 presents the research design and data collection strategy, Section 4 analyzes uptake of the standalone weather index insurance product and looks at the relative roles of subsidies, covariate risk, and individual-level risk rationing in driving demand. Section 5 uses the individual-level subsidy experiment to analyze impacts of being insured, Section 6 provides a descriptive analysis of the impact of the interlinked product and its limited introduction, and Section 7 concludes.

\section{STUDY CONTEXT.}

\subsection{Inputs and Credit in Ethiopian Smallholder Agriculture.}

Ethiopia is a very poor country by world per capita GDP standards (it ranks 209 out of 228 countries listed by the World Bank). Nevertheless, it has been growing quickly in the last few years (on average 10.2 percent per annum during 2010-14). Agriculture is the main productive sector of the Ethiopian economy. It accounts for a little under 50 percent of the gross

domestic product, provides employment for 80 percent of the population, generates about 90 percent of the export earnings, and supplies about 70 percent of the country's raw materials to secondary activities. Crop production is estimated to contribute on average around 60 percent, 
livestock accounts for around 27 percent and forestry and other subsectors around 13 percent of the total agricultural value of production. Over 95 percent of the cultivated land is under smallholder peasant agriculture. High total fertility rates and low input use have resulted in the exposure of small-holders to natural resource degradation, soil erosion, and food insecurity, and over the long run will likely damage the prospects for agricultural productivity growth. Nevertheless, in recent years the agriculture sector has been growing fast; 5.9 percent annually between 2010 and 2014 (World Bank, World Development Indicators).

Most of Ethiopian agricultural production takes place under rain-fed conditions and is subject to considerable weather variation. Dercon and Christiaensen (2011) found that fertilizer use in Ethiopia, while profitable, is risky, and that the lack of insurance against risk leads to low input use and inefficient production choices. These results provided the motivation for the project reported in this paper. Risk aversion is well accepted as a factor inhibiting the adoption of fundamentally new technology such as chemical fertilizers and improved seeds. In addition to production risk, Dercon and Christiaensen (2011) recently showed that ex-ante consumption risk could also affect fertilizer use. Similarly Lamb (2003) showed that risk avoidance in the face of incomplete insurance may be key in understanding limited fertilizer use. Given the transformative effect of agricultural technology on yields, risk-driven barriers to adoption present an obvious potential poverty trap (Christiaensen and Demery, 2007), and hold out the possibility that risk-protecting products such as index insurance may not only provide second-order benefits through variance reduction, but first-order benefits through enhanced willingness to take profitable risks among producers.

Despite large secular increases in fertilizer use and household income over time, overall input use and productivity remain low. ${ }^{4}$ Per hectare fertilizer consumption is less than one fifth of that of other developing countries (Morris, et. al. 2007). Dercon and Hill (2009) report that fertilizer intensity per hectare of fertilized area has not increased between 1997/98 and 2007/08, despite the apparent doubling of total fertilizer sales during the same period. This can be largely

\footnotetext{
4 A host of demand and supply side factors have been invoked to explain the limited adoption of fertilizer in Ethiopia including limited knowledge and education (Asfaw and Admassie, 2004, Yu et. al. 2011), risk preferences, credit constraints (Croppenstedt, Demeke and Meschi, 2003), irregular rainfall (Alem et. al. 2008), limited profitability of fertilizer use (Dadi, Burton, and Ozanne, 2004), lack of market access (Abrar, Morrissey, and Rayner, 2004), incomplete markets (Zerfu and Larson, 2010), inefficiency of input use (Yu et. al. 2011), as well as limited or untimely availability of the inputs themselves.
} 
explained by a heavy reliance on extensification, via expansion in the cultivated area. The use of the primary fertility-enhancing agricultural technologies such as irrigation, fertilizers and pesticides is lower than in other regions of the developing world, sharply limiting yield gains. Rashid et al. (2013) indicate that only 19 percent of total cultivated area is fertilized, although Amhara, the region of this project, exhibits somewhat higher input use than the Ethiopian national average. They also show that cereals, especially teff, are the main crops that receive fertilizer. They estimate the value-cost ratio $(\mathrm{VCR})^{5}$ of fertilizer, and found it for most cereals and regions generally close to or larger than 2, normally considered the minimum necessary in Africa for adoption of fertilizer.

The absence of productive credit may be an important reason for the low use of improved inputs and hence lower productivity among African rural smallholders. Many studies have found that small farmers in developing countries are credit constrained and as a consequence use few purchased inputs (Besley, 1995; Conning and Udry, 2007). ${ }^{6}$ On the supply side, banks may find it very risky and expensive to provide credit to rural smallholders, thus rationing the supply of credit or making available contracts that maybe too expensive or too demanding on collateral. On the demand side, apart from the situations where farmers may not have adequate collateral, even in situations where credit is available farmers may find it too risky to borrow (Boucher, Carter and Guirkinger, 2008). Recently Abate et al. (2015) showed that access to institutional finance has significant positive impacts on both the adoption and extent of technology use in Ethiopian agriculture. They also showed that cooperatives have a greater impact on technology adoption than do Micro Finance Institutions (MFIs). The high cost of credit also adds to the cost of fertilizer. According to the Ethiopian Rural Household Survey 1994-99 (ERHS), in 199971 percent of those purchasing fertilizer used formal seasonal credit provided via parastatals, and the implicit median interest rate was calculated at 57 percent (Dercon and Christiaensen, 2011).

The system of input distribution and financing in Ethiopia has evolved over time, but consistently features a dominant role for state-led actors. While thriving private output markets exist, the government is responsible for fertilizer imports, and the cooperative sector is used as the primary delivery vehicle for most improved inputs. In Amhara state, the Cooperative Unions

\footnotetext{
5 The VCR is the ratio of the value of incremental output to the value of fertilizer used for this output.

${ }^{6}$ Other recent analyses, however, emphasize the poor quality of soils that make adoption unprofitable (Marenya and Barrett, 2009), or the heterogeneity of farmer profitability of fertilizer use (Suri, 2011).
} 
handle the wholesale demand aggregation function, pre-ordering inputs through a public enterprise (AISE), and also serving as a conduit to financing through the publicly owned Commercial Bank of Ethiopia. State governments have played a critical role in underwriting the risks of smallholder input financing, and are not averse to finding ways of shedding this risk. Our fieldwork found that the financing chain in recent years has been subject to a game of chicken, whereby the government had announced early in the season that fertilizer would be distributed on a cash-only basis, but once it became clear that this would result in low demand and excess stocks of fertilizer they injected public-sector credit later in the season.

Motivated by the importance of financing to increasing input use, and by the intimate relationship between agricultural risk and the availability of this financing, we worked to create an interlinked credit and insurance product as a part of the study. Index insurance allows some of this systemic risk to be passed onto international reinsurers (Carter et al., 2015), as has been done through Mexico's Cadena program (Duru et al., 2016b). Dashen Bank was willing to attempt to lend to the (potentially vast) smallholder market given the backing of Nyala's insurance, but had to seek a modality to make this viable given the very small scale of the anticipated loans, the lack of pure private-sector lenders in the sector, and the fact that the government owns all land in Ethiopia making standard land collateralization non-viable. Their solution to this, given the input focus of the project, was to work with the cooperative sector that is responsible for providing almost all improved inputs at the village level. Village-level cooperatives would aggregate demand for the interlinked loans, pass it on to the Unions, who would in turn sign a single loan contract with Dashen for all their sub-cooperatives, collateralized by the productive assets of the Union.

This solution represented a potentially fundamental reshaping of the way in which agricultural risk was apportioned in the credit system, and many parties were eager to see this happen. In the end, fielding the interlinking proved to be a substantial logistical challenge. The current public credit system puts the suasion of the government (the most credible institution in the country) on the line, and permits the use of extension agents, police, and other officials in the debt collection process. ${ }^{7}$ Recognizing the exposure it faced as a private sector entity newly

\footnotetext{
${ }^{7}$ The largest parastatal lender in the study credit system at present is the Amhara Credit and Savings Institution (ACSI); some of the means applied by ACSI to compel repayment has led to discontent amongst the customers.
} 
entering a market previously so dominated by the state, Dashen insisted that the Cooperative Unions (CUs) have a stake in the successful recovery of loans through the interlinked product via collateralizing the loans with CU assets. Unions are cooperatively managed entities with a somewhat ambiguous legal status, and this requirement to use their own assets to leverage credit for members was new and difficult to negotiate. This tension suggests a fundamental issue in the process of interlinking: the fact that the index insurance product itself generates little or no moral hazard does not remove the problem of moral hazard from the credit side of an interlinked product, and maintaining the discipline of a culture of repayment may be particularly difficult when an interlinked product introduces states of the world in which a loan does not need to be repaid. While the ambiguous legal status of the Unions may be localized to the Ethiopian context, it is a fundamental challenge to reallocate weather-driven default risk in a way that retains the incentive compatibility of repayment in the absence of a weather shock. Given the design of our financial product, the collateralization of the assets of the quasi-public CUs turned out to be the place where this non-weather driven risk became concentrated and consequently proved one of the most difficult steps to negotiate.

All five Cooperative Unions in the project implementation area attended workshops intended to facilitate the understanding and development of the interlinked product, as well as providing financial documents to Dashen that let the bank begin to assess their creditworthiness and begin the contracting mechanism. In the end, only one Union (Merkeb) was ultimately able to clear the various hurdles required to receive loans from Dashen, and they ended up providing interlinked loans to a single village, Feres Wega. Credit did not reach the famers in this village until after the fourth and final round of the full household survey. We did nonetheless design a special survey instrument that was fielded in Feres Wega in a fifth round (in early 2016), including all 20 of the panel individuals that we had previously been tracking and 100 additional randomly sampled households among those who took up the interlinked product. We present descriptive analysis of what transpired in this village using all five survey rounds in Section 6 of the paper. All insurance sold during the randomized phase of the study was standalone, and hence the experimental results of the study speak only to standalone insurance. 


\subsection{Index Design.}

We now describe the insurance product in more detail. The focus of the project was to improve input use and therefore the insurance product was conceptualized as insuring the value of inputs rather than trying to cover the variation in the value of output. The input purchases of an average-sized farm operating at the input intensity recommended by the Ministry of Agriculture would be roughly 4,000 birr (\$278). We worked with an agronomic expert to build a crop water requirement model for every village and every crop for which we sought to offer insurance, namely teff, wheat, sorghum, and maize. The contract took a standard 'trigger and exit' form, whereby the payout was a linear function of rainfall below the point at which the agronomic model began to predict agricultural losses and then made a complete payout on the contract once the cumulative rainfall fell below the critical value for that location and crop.

The farmer could choose to purchase whatever multiple or fraction of this contract he/she wished. The contract stipulated a graduated payment based on a rainfall index, which was based on rainfall observed at a station nearby (namely a distance less than $20 \mathrm{~km}$ ). The productive season (which for the project was the Meher season in Ethiopia (June, July, and August the three rainy months, which constitutes the main growing season) for each crop was divided in three segments (early, growth, and maturation), and a maximum and minimum rainfall level were specified for each period, relating to the zero and full damage to the crop respectively. Similarly the maximum payout in each period was specified. The actual payout was estimated as an increasing share of the rainfall deficit from the maximum in the given period, so as to be zero for rainfall above the maximum (exit), and 100 percent of the period amount, if rainfall was below the minimum threshold (trigger). ${ }^{8}$ The rainfall data utilized was decadal rainfall data, covering a period of approximately 40 years, and obtained from the National Meteorological Agency (NMA) of Ethiopia. The definition of periods and trigger and exit points, was based on agrometeorological models of crop water requirements developed at the Food and Agriculture Organization (FAO) of the United Nations, and was specified so as to give a full crop failure approximately once every 10 years (see Figure for an example of a typical trigger and exit

\footnotetext{
${ }^{8}$ Appendix Figure A1 provides a visualization of how the trigger (entry) and exit values map to the rainfall distibution.
} 
product structure). The entry and exit probability values are selected as 0.2 and 0.1 , respectively indicating some payout every 5 years and full payout every 10.

Premium costings were accordingly based on the average payout to farmers, had the system been operated historically over a long time period. Since the number of years with precipitation data is relatively short (normally 30 years, but actually shorter in many cases because of missing data), a classical stochastic weather generator (M\&Rfi) was used to generate 500 years of data with the same statistical properties as the years actually observed. ${ }^{9}$ The premia thus calculated were different in different zones, given their different rainfall probability profiles. The use of the crop water requirement model is built to measure stress on the crop, and hence that actuarially fair prices are higher in drier locations, and so our product was expensive where it was most valuable and inexpensive where it triggered less often. The final market premium price was augmented by 25 percent above the actuarially fair premium to provide the commercial margin for NISCO in offering the product.

\section{EXPERIMENTAL DESIGN \& DATA COLLECTION.}

\subsection{Study Sample Selection.}

This study originally consisted of a village-level randomization of access to insurance, and a household-level experiment in the offering of free insurance vouchers. In the end, we suffered from attrition in the potential sample of study villages subsequent to the village-level randomization, and the reduced number of locations makes this comparison low-powered. However, we conducted multiple waves of individual randomization subsequent to the reduction in sample size, and this individual-level experiment that is both internally valid and relatively high-powered statistically. We now describe the process by which the final experimental sample was selected and assigned to treatment.

The identification of the original 120 study villages (kebeles) in Amhara state was conducted by Nyala Insurance, who selected regions that were generally drought-exposed, within

\footnotetext{
${ }^{9}$ M\&Rfi includes a Markov chain (where sequences of dry/dry, dry/wet, wet/dry and wet/wet periods are taken into account), that models rainfall using a Gamma distribution to take account of the positive skew in the rainfall distribution (many low values with some high values) as well as an autoregressive model to take into account pseudo-cycles (Dubrovský 1997; Dubrovský et al 2000, 2004).
} 
$20 \mathrm{~km}$ of a rainfall station, and that they believed to be good markets for weather insurance with well-functioning village cooperatives (see Figures $1 \mathrm{~A}$ and $1 \mathrm{~B}$ for a map of the study area. The selection of the Kebeles was purposive, and designed on the basis of informed opinion of NISCO as to where in the Amhara region the market for WII has best potential. ${ }^{10}$ Within study villages we then randomly sampled 18 Households from within the membership of the village agricultural cooperative, and 2 households from the non-cooperative farming population of the village. ${ }^{11}$ Table A1 provides summary statistics by district from the baseline, underlining the large household sizes and extremely low education rates prevalent in our sample. ${ }^{12}$ We conducted a second, shorter baseline survey in 2012 collecting the primary agricultural outcomes only so as to provide a more powerful estimate of pre-treatment outcomes, as advocated in Bruhn and McKenzie 2009).

The baseline data were used to conduct a village-level randomization stratified on average fertilizer use and blocked on region, that assigned villages into three arms of 40 villages each: standalone villages in which WII and voucher subsidies were offered, interlinked villages that offered standalone WII as well as trying to field the interlinked product, and a control.

Between the 2011 baseline and the 2103 Round 3 survey we worked to develop and field the insurance products. In the process we encountered several distinct obstacles that led to alterations relative to the additional study design. First, as described above, no Cooperative Union was able to stand up the interlinked product during the experimental phase of the study, so both treatment arms received standalone insurance. Second, the baseline surveys uncovered the fact that (despite the fact that we were working in a drought-exposed region of Ethiopia) a significant share of the villages reported in the baseline survey that they suffered primarily from excess rainfall or frost risk, rather than the deficit rainfall risk the index was meant to address. ${ }^{13}$ Third, as NISCO pursued reinsurance cover for the project from the large Swiss reinsurance

\footnotetext{
${ }^{10}$ The zones in Amhara are North Shewa, West Gojam, South Wello, and North Wello

${ }^{11}$ Because fertilizers are procured exclusively through primary cooperatives and their upper level zonal Cooperative Unions (CUs) in Ethiopia, it was anticipated that cooperative households may display a higher propensity to uptake additional fertilizer if risk concerns can be ameliorated. We focus the analysis in this paper on the cooperative membership only.

${ }^{12}$ From Table A1 it can be seen that 51 percent of household heads have no education, only 21.5 percent received any formal education, among whom the average years of schooling is 4.8 years. A full 56.5 percent of household heads cannot read or write.

${ }^{13}$ The tremendous elevation variation of the topography in Ethiopia means that nearby villages can face extremely heterogeneous exposure to risks such as frost or drought.
} 
company Swiss Re, the reinsurer indicated that only 9 of the 26 rainfall stations that covered the original study had sufficient historical coverage and quality of rainfall data to be reinsurable. To maintain the internal validity of the experiment in the face of these implementation obstacles, we reduced the study sample to include only villages that a) suffer from deficit rainfall risk and b) are located within $20 \mathrm{~km}$ of a re-insurable rainfall station (see Figures 1a and 1b for maps of the final study area and rainfall stations). This reduced sample, which forms the basis for the analysis conducted here, consists of 49 villages, of which 17 were in the standalone arm, 17 in the interlinked arm, and 15 in the control. Figure 2 presents a CONSORT-style diagram illustrating the evolution of the study sample.

We then attempted to track all study households in these villages, and achieved a four-round tracking rate of $92.5 \%$. Tracking this sample of 20 households each in 49 villages, we conducted two post-treatment household and cooperative-level surveys, one in 2014 and one in 2015. Table A2 shows summary statistics across survey waves, painting a rather dire picture as to the depth of poverty in our sample. More than 75 percent of households in Round 1 stated that they did not have enough, or had just enough, income to cover food needs, and only 4.4 percent stated that their income is adequate to cover all their needs. However, food insecurity declines strongly over time, falling to 56 percent in the the 2014 survey. Table A3 shows that while rates of fertilizer use have improved quite dramatically over the period of the study (from just over half to almost three-quarters), land fragmentation is proceeding rapidly. The average size of farmland owned was 1.47 Ha in $2010 \mathrm{Ha}$, while the average land cultivated was 1.63 Ha in 3.7 parcels. By 2013, the average area owned had fallen to $1.18 \mathrm{HA}$ and the average area cultivated to $1.1 \mathrm{Ha}$ in 3.5 parcels. Clearly most of the households in the sample are quite poor, despite the intention to pilot the project in areas thought to be better off and with higher agricultural potential. Finally in early 2016 a small group of 120 households in the only kebele which successfully fielded the interlinked credit-insurance product were surveyed (R5). Given this attrition subsequent to randomization we do not place too much weight on the cross-village comparisons.

\subsection{Individual-level Study Design.}

Fortunately, the experiment also feature two dimensions of insurance implementation that were randomized at the individual level within the treatment villages subsequent to the villagelevel attrition. First, at the time of the baseline survey we selected a random subset of households 
to receive a promotion and training in the way that the index works. Because we were concerned that the indirect marketing techniques used by Nyala might generate only an imperfect understanding of the product (they trained village level agricultural extension officials to work with village cooperative leaders to promote the product to farmers) we employed the EEA to conduct these randomized promotions as a part of the baseline activity.

Secondly, in all years where rainfall insurance was offered, a small subsidy towards the premium was individually randomized to a subset of the farmers selected for survey in each treatment kebele. Subsidy amounts were offered in three sizes, covering 10, 30, and 50 percent of the average premium (calculated as a function of average land size and the recommended input usage in Amhara). Each type of subsidy was offered to 5 farmers in each kebele. Given 34 treatment kebeles, a total of 170 farmers received each type of subsidy for a total of 510 farmers out of the 680 farmers surveyed in the treatment kebeles. In sales season 2, voucher subsidies were re-randomized at the individual level. Table 2 presents the final design of the individuallyrandomized component of the study study in the 49 villages that were panel tracked as a part of the survey.

\subsection{Attrition and Balance.}

Table 3 analyzes the extent to which the two types of attrition from the study are correlated with baseline outcomes. First, in columns 1 and 2 we examine the determinants of the villagelevel attrition as the study sample was selected down from 120 to 49 villages. This source of attrition may be less problematic for the study in that our original sample was anyways purposive, and we will focus most of our analysis on the individual-level experiments conducted within these villages. The first column shows that the factors eliminating villages (no exposure to rainfall risk, rainfall stations that could not be reinsured) are not correlated with the randomly assigned treatment status, but column 2 makes it clear that the attrition of villages from the study was non-random in a number of ways, with the remaining sample consisting of more commercial farmers, and more of those who hire in labor. Given the substantial village-level attrition rate of $59 \%$ subsequent to randomization, the cross-village component of the study is not cleanly experimental.

The randomization of vouchers, however, was conducted at the household level subsequent to the attrition, and hence still provides a clean and internally valid experiment for 
understanding the impact of insurance on farmer behavior. For this reason, and because the insurance actually sold during the period covered by our panel study was all standalone, we control for the village-level treatment status but focus the analysis on the vouchers for which we have a clean experiment. Columns 3 and 4 of Table 3 test whether the standard panel survey attrition between waves 1 and 4 is correlated with treatment, and with a set of baseline covariates. This analysis shows that receiving a sales voucher is strongly predictive of remaining in the study; within treatment villages the attrition rate for those who did not receive a voucher was 9.7\%, while for those who received vouchers it was only $1.7 \%$, with the difference significant at the 95\% level. Column 5 shows the results of a regression that includes the dummy for 'Any Voucher Ever', the same covariates as Column 4, and the interaction between treatment and these covariates. For parsimony we report only the interaction terms in this column, plus the p-value on the F-test that all interacted terms are jointly insignificant. Unfortunately, we reject this F-test indicating that not only did the voucher treatment decrease attrition overall, but it systematically decreased attrition most for younger $\mathrm{HH}$ heads. We return to this issue in the results section, presenting attrition-corrected estimates of our main impact table using Inverse Propensity Weights calculated on the basis of the regression in Column 5.

Potential problems with differential attrition make us particularly interested in with the balance of the experiment within the final attrited sample used for analysis. Table 4 analyzes the extent to which the intervention and comparison groups are comparable within the panel sample. The table includes coefficients to test the balance of the village-level randomization as well as the individual-level voucher experiment in both the first and the second sales seasons. Since both the receipt of any voucher and the amount of the voucher received will be used in the subsequent analysis, we examine the balance of both these variables. Overall, the study appears well balanced. We present 114 comparisons in Panels A and B of the table (19 variables, six dimensions of randomization) and find 10 relationships to be significant at the $10 \%$ level and 3 at the $5 \%$ level, very much what we would expect by random chance. We find absolutely no sign of imbalance in the primary outcomes for the study in Panel B. We therefore proceed to the experimental analysis of uptake and impacts confident that we have a small but internally valid sample, and placing our emphasis on the household-level randomization of vouchers which is both subsequent to the main attrition in the study and is of higher statistical power than the village-level experiment. 


\section{UNDERSTANDING AND UPTAKE OF THE INSURANCE.}

\subsection{Demand With and Without Subsidies.}

Table 5 shows simple summary statistics of the rate of take-up and the average sum insured across the various years and arms of the study. The study featured only one-sided noncompliance, meaning that there were no individuals who received insurance in the control villages at any point in the study. Distressingly, there were no surveyed households who ever purchased insurance in the absence of being given a subsidy to do so, and it was typically the case that individuals 'purchased' mainly the amount provided by the voucher and rarely put their own money into insurance premium payments. Overall, the fraction of the total membership of treatment cooperatives who purchased insurance in the absence of any subsidy is roughly .5\%, suggesting that the insurance, as priced to reflect all costs, was simply not viable as a commercial product. The average amount of farmer money put into the purchase of the insurance during the first sales season was $\$ 5.16$, and during the second season was $\$ 4.32$. This means that the study finds little true willingness to pay for commercial weather index insurance, and what we study here is almost exclusively the decision to accept free insurance, and the impact of receiving it. Willingness to accept the standalone insurance among cooperative members was very steady across the two rounds at $43 \%$, despite the fact that vouchers were cross-randomized. Consequently, as shown in Figure 3 the average sum insured at the individual level is an almost linear function of the voucher amount, a feature we exploit in Section 5.2. The sum insured was slightly higher in the first sales season than the second because the voucher amounts were larger. Non-cooperative members take up standalone insurance at about 2/3rds the rate of coop members.

\subsection{The Dynamic Effect of Subsidies.}

The preceding subsection illustrated that demand for the product was vanishingly small in the absence of subsidies, but that vouchers for insurance created strong variation in the rate at which individuals were successfully issued insurance policies by Nyala. Given the now wellrecognized problems of demand in launching a new index insurance product, however, a business case for subsidies can still be made if they have strong enough effects on subsequent demand, 
and positive dynamic effects of subsidies have been suggested in the context of learning about the new probability distribution of farmer income (Cai et al., 2016). Our study provides a very simple environment in which to pose this question, because we independently randomized subsidies in the first and second sales seasons (measured using survey waves 3 and 4 , respectively), meaning that we can examine the impact of first-season subsidies $T_{i c 1}$ and secondseason subsidies $T_{i c 2}$ for individual $i$ in cluster $c$ on second-season demand $D_{i c 2}$, using the crosssectional regression

$$
D_{i c 2}=\beta_{0}+\delta_{1} T_{i c 1}+\delta_{2} T_{i c 2}+\varepsilon_{i c 2} .
$$

Standard errors in this regression are clustered at the village level to reflect the design effect. This table, as all of the main tables in the paper, is estimated only using the sample of cooperative members. This first pass at this question is provided in Column 1 of Table 6, which analyzes the impact of subsidies in the first and second year on the uptake of insurance in the second year. The first clear result from this table is that the vouchers have strong contemporaneous effects on the probability that an individual is protected by insurance; uptake is elevated by $43 \%$ in the presence of subsidies, and the sum insured is driven strongly by the amount of the voucher subsidy in that season. The dynamic subsidy argument requires that subsidies create more permanent demand, however, and when we look at the effect of season 1 vouchers we find no effect that has persisted into season 2 . The point estimate on this term is very small (.7\%) and far from significant. Column 2 shows that the voucher amount has no effect on uptake either concurrently or subsequently. The impact of the voucher amount on the sum insured displays a similar pattern; strong contemporaneous effects but no detectable dynamic effect at all.

Next, we pursue the idea suggested by the results of Karlan et al. (2014) that an effective way to build demand is to bolster the credibility of the project by providing subsidies until individuals see that payouts are really being made, at which point they will become more willing to purchase insurance at market prices. To test this, we define a dummy variable $P_{\text {icl }}$ based on the rainfall realizations at the local rainfall station and the main crops that a farmer grows, to indicate that they would have received a payout in the first sales season had they decided to purchase insurance (the variable is constructed in the same way for the treatment and control). We then interact this variable with the (randomized) season 1 vouchers. 


$$
D_{i c 2}=\beta_{0}+\delta_{1} T_{i c 1}+\delta_{2} T_{i c 2}+\eta_{1} P_{i c 1}+\eta_{2}\left(T_{i c 1} \bullet P_{i c 1}\right)+\varepsilon_{i c 2}
$$

The uninteracted term therefore tests whether having payouts made in your village for your crop to others around you induces subsequent demand, and the interaction term tests whether this effect is bigger for those who received vouchers, roughly $40 \%$ of whom would actually have received insurance. Column 3 shows that neither of these terms is significant, indicating that neither the presence of historical payouts nor the receipt of subsidies in combination with payouts leads to increases in demand. Colum's 4-6 show similar results on the sum insured; while this outcome responds more strongly to the contemporaneous voucher amount, there is still no impact of lagged voucher receipts. Consequently, this relatively well-powered demand experiment provides no evidence that temporary subsidies resulted in a durable improvement in demand for index insurance.

\section{IMPACT OF BEING INSURED.}

\subsection{Intention to Treat Effects.}

Roughly $40 \%$ of those offered insurance policies accept them and we have no take-up of insurance in the study sample other than through the subsidies. This implies that what would otherwise have been a low-powered clustered experiment is instead a relatively well-powered individual design with which to measure the ITT of offering small free insurance policies. We now proceed to exploit this experiment to track out the impact of being insured on the primary objective outcomes of the study: use of fertilizer, use of improved seeds and credit, agricultural yields, and household income. Our regression specification is the standard panel fixed effects difference-in-differences, namely:

$$
y_{i c t}=\alpha_{i}+\delta_{t}+\beta_{1} T_{c t}+\beta_{2} V_{i c t}+\varepsilon_{\text {ict }}
$$

Here $\alpha_{i}$ is an individual fixed effect, $\delta_{t}$ is a fixed effect for each of the post-treatment survey waves, $T_{c t}$ is a panel treatment dummy that switches on in treatment villages for rounds 3 and 4 , and $V_{\text {ict }}$ is a panel dummy variable indicating that the individual received a voucher in that season. We cluster standard errors at the kebele level to account for covariance within the cooperative, as well as the village-level design effect. Given this specification, $\beta_{1}$ is the impact 
of being in a treated village and not receiving a voucher, and $\beta_{2}$ is the ITT impact of receiving a voucher. Based on the uptake analysis, we expect $\beta_{1}$ to be zero and we are primarily interested in the sign and magnitudes of $\beta_{2}$.

We also present a more complex ITT structure that is based directly on the design of the experiment, meaning that we include separate dummies for the standalone and interlinked treatment arms, the voucher amount, and we allow the vouchers to have different impacts in each of the two treatment arms. This specification is then:

(4) $y_{i c t}=\alpha_{i}+\delta_{t}+\gamma_{1} T_{c t}^{S}+\gamma_{2} T_{c t}^{I}+\gamma_{3} V_{i c t}+\gamma_{4} V A_{i c t}+\gamma_{5}\left(V A_{i c t} \cdot T_{c t}^{S}\right)+\gamma_{6}\left(V A_{i c t} \cdot T_{c t}^{I}\right)+\varepsilon_{i c t}$.

In this specification $T_{c t}^{S}$ and $T_{c t}^{I}$ are dummies for the standalone and interlinked treatments, $V A_{i c t}$ gives the amount of the voucher, and $\gamma_{5}$ and $\gamma_{6}$ test whether the vouchers or voucher amounts have differential effects in the standalone arm relative to the interlinked arm.

Table 7 presents the results of this analysis, using specification (3) in Panel A and (4) in Panel B. For comparability we repeat in Columns 1 and 2 the analysis of uptake, presenting a binary outcome for any insurance coverage (which in this case means accepting the free insurance policy) as well as a continuous outcome for the sum insured in that season. Beginning with Panel A, we focus our estimation on the row for 'Any Voucher' $\left(\beta_{2}\right)$, which generates a very large first-stage effect on uptake of the insurance. Troublingly, none of the three variables describing the use of fertilizer are significantly affected by the provision of insurance vouchers, despite the fact that $39 \%$ of the individuals in this group are insured. The use of any chemical fertilizer rises by a mere 2 percentage points off a base of 55\%, and this effect has a t-statistic below one. The number of kilograms of chemical fertilizer used actually falls by 1.76 , or $2 \%$ of the baseline mean, and the number of crops on which fertilizer is used sees a similar small decline. Turning to the use of improved seeds we see an apparently impressive increase of 6 percentage points, but a more careful examination shows that this is relative to a decline of 12 percentage points in treatment villages for individuals who do not receive vouchers (both effects significant at 10\% level). Credit use does not increase. As we would expect when inputs to the agricultural process remain unchanged, yields are similar across groups and household income remains unchanged by the receipt of the free insurance voucher. 
Against this discouraging picture of the impact of index insurance vouchers, it is important to highlight the remarkable improvements apparent in the round dummies. The use of chemical fertilizer surges overall during the course of the 2012 (R3) and 2013 (R4) seasons, the fraction of farmers using fertilizers rises from a control average of 54\% in 2010-2011 to $77 \%$ in 2012 and 73\% in 2013. The average number of kilograms used goes from 91 to 107 in 2012 and 108 in 2013. Correspondingly, average household real income is 55\% higher in the endline than it was in the baseline. This large increase must be qualified by the fact that during 2012 and 2013 inflation was quite high in Ethiopia (in the order of 20-30 percent) and hence it was quite difficult to estimate an inflation factor specific to the area of the study. Various attempts using individual product price changes, and zonal figures gave quite different estimates. Nevertheless, the welfare improvement during the period is real, as reflected for instance in the large decrease of the share of household who report not having enough to eat, along with the increase of the share of those who report they have enough for food and necessities (table A2). So it is important to recognize that lack of insurance impacts is measured during an interval when the target outcomes of the study were strongly improving overall.

Does the lack of impact arise from a lack of statistical power? Clearly the village-level insurance experiment in our reduced sample is underpowered. Examination of the standard errors on the individual-level voucher experiment, however, suggests that power is not a major concern. Multiplying the standard errors on the impact coefficients in the first row by 1.96, we would be able to detect an increase of at least 7.5\% in fertilizer use, and 6.5\% in improved seeds or credit. For fertilizer, this represents a standardized effect size of .15, represented as a fraction of the standard deviation of this variable in the baseline control. These is a relatively small standardized minimum detectable effect, indicating that the voucher-level experiment is adequately powered. Further, we see negative coefficients on two of the three variables describing the primary fertilizer outcome, and we clearly have plenty of power to detect the cross-period changes in input use and incomes. Hence, while the final study sample is less well-powered than the original design intended, we can conclude that at least the individual-level voucher treatment did not result in any substantial improvement in input use or incomes during the period of the study relative to the absence of a voucher. 
Could the lack of impact be coming from the differential attrition by voucher status demonstrated in Table 3? Appendix Table A4 replicates Panel A of Table 7 using inverse propensity weights (calculated using a battery of baseline covariates and their interactions with voucher treatment status). This effectively reweights the treatment and control samples to be equivalent on the observable variables that were found to be differentially imbalanced in Table 3. These results look very similar to Table 7 , suggesting that the impacts among the attrited and non-attrited groups are broadly similar (at least on observable variables), and hence attrition is unlikely to be driving our results. Pursuing a more conservative approach to attrition, such as Lee Bounds, is not informative in the context of the broadly insignificant impacts of the study.

Panel B of Table 7 examines the data using the originally intended study design, separately looking for impacts in standalone and interlinked villages using Equation (2). The results of this table indicate that the more parsimonious specification already presented was not masking any strong impacts within sub-groups of the treatment. While there are significant cells, this table presents 48 impact tests on the primary outcomes and hence we expect some significance by random chance. The overall picture is the same; where the results indicate a positive effect of being insured (such as the use of improved seeds), these are generally in the context of secular declines in treatment villages for those not receiving vouchers, meaning that nowhere do we see clear evidence that the treatment corresponds to an absolute expansion in absolute input usage for those getting vouchers.

What else can explain this lack of impacts? We now attempt to gauge the relative importance of four distinct mechanisms. First, it is possible that the voucher amounts were simply too small to generate a meaningful change in behavior. Second, if only a small fraction of the population we studied was constrained by risk in investment decisions, we may not have relaxed a salient barrier to input use in the broader population. Third, it may be that the implementation of the treatment was weak and poorly understood, and so farmers simply did not understand the insurance well enough to respond. Finally, given the rigid and state-dominated input system in Ethiopia, it is possible that individual farmers did not have sufficient latitude to respond to the relaxation of risk constraints by changing input use in a meaningful way. We now take each of these explanations in turn. 


\subsection{Impacts of the Sum Insured, using Voucher Amounts as an Instrument.}

To investigate whether the lack of impacts in our sample arise from the small average amount of the vouchers, we pursue two approaches. The first of these is to exploit the fact that the randomly assigned voucher amounts generate very strong experimental variation in the sum insured. This is due to a combination of the invariance of uptake rates to voucher amounts and the low prevalence of individuals purchasing their own insurance. Figure 3 illustrates this relationship, showing the almost perfectly linear relationship between the voucher amount and the sum insured, and illustrating that at the highest voucher amounts the sum insured is nearly $\$ 80$, representing $55 \%$ of the total value of inputs observed in the control group, \$147. Given this strong relationship, we can think of estimating the slope of a linear IV impact of sum insured on outcomes, instrumenting for the (endogenous) sum insured with the randomly assigned voucher amounts. This analysis is presented in Panel A of Table 8. Column 1 shows the first stage of the IV regression, indicating that the instrument has a t-statistic of 6, and the IV regression should be well powered to detect impacts. Columns 2-9 present these instrumented impacts on the battery of primary outcomes, illustrating that even when we translate impacts into the marginal effect of the sum insured, we are unable to detect any significant changes in inputs or agricultural productivity as a result of the insurance.

A second way of tackling this question is to isolate the impact of receiving the largest voucher amounts. We do this by defining a separate dummy variable that indicates being treated with the largest voucher amounts, which we characterize as the vouchers for 300, 400, and 500 Ethiopian birr (\$20.83, \$27.78, and \$34.72). Panel B of Table 8 includes separate dummies for the large transfer amounts and the smaller transfer amounts, and at the bottom of the table we present an F-test of the difference between the two impacts. As in Panel A, there is no indication that the study provided any transfers that generate significant impacts; neither of the two voucher dummies is significant and nor is the difference between them, for any of the primary outcomes in the study. While we cannot, of course, speak to the impacts that would have been observed had we distributed larger vouchers, we find no indication that even the largest subsidies in our study had any meaningful impact on investment behavior. This is suggestive that the overall lack of impacts is not arising simply from small average subsidies. 


\subsection{Differential Impacts by Risk Rationing Status.}

A second explanation for low uptake and small impacts would be that only a small share of the farmers in our sample were constrained in their input investment behavior by the presence of risk. In this case, potentially large impacts in the risk-constrained group could be swamped in the Intention to Treat analysis by the small numbers of such individuals. This suggests a heterogeneity analysis where we distinguish the analysis of uptake and impacts by whether individuals were risk constrained at baseline. This is a sub-group analysis that we anticipated in our earliest project documents, and we carefully classified the credit rationing status of households at baseline using the approach outlined in Boucher et al. (2008). In this typology, we use a set of survey questions on the access to and use of input credit to classify farmers into four constraint categories: unconstrained (currently using credit), quantity rationed (would not be able to access credit), price rationed (could get loan but find it too expensive), and risk rationed (could get loan and would be able to cover interest costs on average, but unwilling to bear the risk of possible default). Overall, we classify $54.6 \%$ of our sample as unconstrained, $18.8 \%$ as quantity constrained, $6.8 \%$ as price constrained, and $19.8 \%$ as risk constrained. Standard agricultural investment models such as Bardhan and Udry (1999), Boucher et al. (2008), and Carter et al. (2015) would all predict that the first-order impacts of insurance on expanding the willingness to borrow and invest in inputs will be strongest in the risk-constrained group.

Table 9 shows the results of this interaction analysis. In order to present the raw effects of the credit rationing status of the household we run this regression as a DID without householdlevel fixed effects. As in previous tables, Columns 1 and 2 show the uptake variables (dummy for purchased insurance and the sum insured), and in neither case does credit rationing status drive uptake, either in absolute terms or in interaction with the receipt of a voucher. When we look at the study outcomes in Columns 3-10, we see that those who were identified as credit rationed at baseline have sharply lower input investment overall: they are 12.5 percentage points less likely to use any fertilizer than the unconstrained, they use $40 \mathrm{Kgs}$ less fertilizer and use it on roughly half the number of crops, and total input expenditures among the risk constrained are only about $2 / 3^{\text {rd }}$ s of those of the unconstrained. Despite these large cross-sectional differences, there are no signs of significant differential impacts of the provision of vouchers on the risk constrained; while the point estimates on the interactions are positive for many of the inputs, total 
value of inputs and yields are both slightly lower for risk constrained individuals offered vouchers than unconstrained individuals offered vouchers. Hence, we uncover no evidence that the lack of demand and impact in our sample is masking large impacts among the subset of individuals whose input investment decisions are most constrained by the presence of risk.

\subsection{Comprehension and Trust of the Index Insurance Product.}

In the round 4 endline, we conducted a survey in treatment villages that asked household heads to describe what they knew of the Nyala index insurance product, how they had learned about it, and what their experiences with the product had been. In terms of awareness of the product and understanding of the voucher distribution, farmers appear to have been properly sensitized. $88.3 \%$ of surveyed cooperative members in treatment villages reported having received information about the insurance, although Nyala's strategy of indirect marketing can be clearly seen in their sources of information: $81 \%$ reported EEA ${ }^{14}$ (the survey entity) as their primary source of information about the product, 8.3\% the cooperative leadership, and only 5.4\% reported getting information directly from a Nyala representative. ${ }^{15}$ A promotional brochure that was developed by Nyala and distributed by EEA had been seen by 56\% of households, and 73\% of households reported understanding the product 'very well' (9\%) or 'partially' (64\%). Recall of the voucher amounts that had been distributed was excellent; of the 370 cooperative members randomly assigned to received vouchers in the second sales season, only 6 incorrectly recalled their voucher amounts. So overall the promotional materials for the insurance and the voucher subsidies were distributed on the ground in a manner that closely conformed to the research design, and awareness of the product was high.

When we dig into the details of the product, however, and the extent of trust that farmers felt in the index and the company, the picture is less rosy. When asked the factual question as to the event that would trigger a payout, only $6.4 \%$ of respondents correctly indicated deficit rainfall at the closest rain monitoring station. While 23\% indicated that they simply did not know, the most common answer (44\%) was that payouts would be triggered by crop losses on the respondent's farm. This indicates that the plurality of cooperative farmers in fact believed that they were being offered indemnity insurance. This certainly points to major potential problems

\footnotetext{
${ }^{14}$ EEA is the Ethiopian Economic Association, which functions as a research organization.

15 The remainder reported other sources such as village officials, friends and relatives, etc.
} 
for the insurer in the event of uncovered losses, but it cannot serve as an explanation for low demand or meager impacts because this suggests that farmers believed the product to be closer to a form of perfect insurance than was in fact the case, and were not being dissuaded by the presence of basis risk. Despite this confusion about the index structure, the 22 farmers who reported having purchased insurance and faced an insurable loss all reported having been contacted by Nyala to arrange the payout, and 17 of them had actually received the money by the time of the R4 survey. Thus, it does not appear that disagreements over payouts among the insured, or any actual failure to honor the contact by Nyala, were to blame.

There is a marked paucity of trust and understanding in the nature of the contract. For the 529 farmers who did not put their own money into buying insurance (above and beyond the voucher), we asked them what the primary reasons were that they had not done so. 55\% said they did not understand the product well enough, $17 \%$ said that they feared the payout would come too late to be useful to the household, $10.3 \%$ said it was because of a lack of trust in the insurer, 9.8\% because they felt their yields were too poorly captured by rainfall at the nearest station (basis risk), $4 \%$ said the product was too expensive, and 3.5\% said they didn't face rainfall-driven risk on their farms. The most common thing that farmers said have been done to make the product more attractive is that it should have been explained more clearly.

To strengthen this point it must be realized that index insurance of the type marketed in the project, if permanently offered, will change the ex-post probability distribution of farm returns. In order for this to lead to behavioral change, however, the change must be understood, and the farmer convinced that it will last. Both of these require that the insurance contract is offered in several successive years, and that the farmer perceives that the change is permanent. Clearly none of these can occur in an experiment that lasts a fixed amount of time, and is not somehow guaranteed as to its continuity. This may explain the lack of impact on the main farm variables.

Was there any cost-effective way that the product could have been better promoted so as to improve uptake and impacts? We address this question using an experiment we conducted at the first baseline, in which EEA was hired using research funds to give an extended promotion of the product, including conducting a 15-minute presentation of the details of the product for a randomly selected six households per kebele, discussing and answering any questions the household had about the way the product works, and leaving behind a flyer indicating how Nyala 
would use rainfall at the nearest station to determine payouts, and which historical years the product would have paid out in that village.

Table 10 shows the results of this analysis. We first analyze the core sales outcomes of the insurance; whether insurance was accepted, the sum insured, and then whether any of the famers' own money was spent on purchasing insurance, and how much was spent. Because the promotion intervention was only conducted once, at the time of the first baseline, we analyze outcomes for each round in a cross-section. There is indeed a relatively large effect of the promotion in the first round; it is roughly a quarter the size of the impact of receiving a voucher, and is strongly significant. Importantly, we also see that the promotion significantly increased the amount that farmers were willing to spend of their own money, raising the average out-ofpocket spending by $\$ 2.80$. This is an encouraging result and represents promising potential evidence that in the face of substantially more on-the-ground promotion the product could have generated more substantial private demand. By the second sales season the effect of the baseline promotion has faded; it is no longer significant on the overall accepting of insurance and only increases out-of-pocket spending on insurance by 85 cents. Nonetheless, by the time of the endline survey households that received the promotion are no more knowledgeable about the insurance product than households in the same village who had not received the promotion. Overall, it appears that misunderstanding of the product was rife, that a relatively cost-effective promotion of the product led to a meaningful increase in both acceptance of the vouchers and out-of-pocket expenses, but that demand among those who received the promotion faded over time, and they did not understand the product better by endline. We conclude that distrust and misunderstanding were prevalent causes of low demand, but that potentially cost-effective remedies exist to address the lack of understanding (if not distrust).

\subsection{State-Led Agriculture and Rigidity in the Input Provision Process.}

The heavy state role in the agricultural sector could inhibit demand for a market priced product in a number of distinct ways. Analysis using the data from this project by Duru (2016) shows that where the government's PSNP safety net program was in place, uptake of the insurance was lower. Indeed, even ineligible households in PSNP villages have lower rates of accepting the vouchers than observationally similar households in non-PSNP villages. A similar point has been made about the role of foreign aid in Ethiopia; when smallholders are protected 
by programs for which they do not directly pay, it is difficult (and very possibly not welfareenhancing) to build markets for risk protection for which farmers would pay full price.

Even when free insurance is provided, as was done with our vouchers, the rigidities of the Ethiopian input provision process may inhibit the input usage response at the farmer level. The long planning times involved in the input procurement process, the egalitarian ethos of the cooperatives, and the lack of outside options for purchasing may all limit the ability of individual farmers to adapt their input usage decisions easily. Preliminary evidence that this is the case is provided by the fact that the intra-cluster correlation on the use of chemical fertilizer within the control group across all four rounds is .66, indicating that only one third of the variation in the key input for this study is found within-village.

A simple way of understanding whether the cooperative supply chain generates an inflexible input response is to incorporate into our analysis the two non-cooperative households that were included in both the survey and the voucher treatment in each village. In Appendix Table A5 we conduct analysis of heterogeneity using pooled OLS, including a dummy for the non-coop members, the panel voucher treatment dummy, and the interaction between these two terms. This interaction asks whether a disproportionate response to the treatment is visible in the non-coop members, as might be the case if they had differential access to more flexible sources of inputs or input financing and hence were able to respond more fully to being insured. These results clearly indicate that non-members have significantly lower use of chemical fertilizer overall, and despite relatively low power there is no evidence of a disproportionate response to the treatment among the non-cooperative members. Indeed, most of the point estimates are negative, suggesting that if anything those farmers with access to the cooperative supply chain are in fact more responsive to the treatment.

If the question of rigidity was a driving one, we might also expect that farmers would have a strong preference to receive credit and insurance earlier in the season, since this would give them more time to adjust input usage. When we look in the data we do not see responses consistent with this; only $3.4 \%$ of respondents say that they would have been more interested in the interlinked product if it could deliver credit in a more timely way. Only 9\% of respondents say that the timeliness of the insurance offer was the major issue. So while it is possible that the marginal effects of free insurance on input use would have been stronger in a more demand- 
driven environment, the direct responses of treatment farmers do not suggest that the timing of product offers was a major concern.

In summary, then, we are unable to find corroborating evidence inside our data to suggest that the small voucher amounts, heterogeneity by risk rationing, or rigidity in the input process drive our lack of impacts. The most compelling arguments seem to be a lack of understanding of the product among farmers, and the substantial public safety nets already existing in the Ethiopian context.

\section{DESCRIPTIVE ANALYSIS OF THE IMPACT OF THE INTERLINKED PRODUCT.}

We conclude with a short descriptive analysis of the survey data from the one village in which the interlinked product was successfully developed and marketed, Feres Wega (or FW for short). The product was sold in late 2014 and we conducted this fifth survey in early 2016. In that year (2014) the interlinked product was offered to all farmers in the stated village, and not only to those in the panel. In total, 254 farmers obtained interlinked insurance and credit through the project in that year. We tracked our panel sample of 20 households, and further randomly sampled an additional 100 households from the cooperative membership of FW from among those who had purchased insurance (most of whom also acquired the interlinked loan).

We can use pre-treatment data to explore the differences between FW and the other Kebeles in our sample, which may account for the ability and willingness of the cooperative and its members to to successfully put in place the interlinked product. Household heads in FW are younger and more educated than the average household head in the other kebeles. They are also less food insecure as a smaller share indicate that their income is not enough for even food. Farmers in FW own and cultivate smaller amounts of land, but use inorganic fertilizers and chemicals in larger proportions than in other kebeles. They produce the major crops, teff, barley, wheat, maize, and millet, in higher proportions than the rest. They also have lower income and expenditure per capita. All these taken into account suggest farm households who are headed by younger and more educated farmers, but who cultivate smaller amounts of land with higher input intensity, which, nevertheless, does not provide them with higher income than the other farmers in the sample. These attributes suggest that the farmers in FW maybe more exposed to weather 
risk, and be more credit constrained than the rest of the farmers in the sample, and these a-priori imply more openness to the interlinked product.

Of the 20 households in the panel from FW, 15 had ever received a voucher towards the premium, and 11 bought interlinked insurance for an uptake rate of 55 percent. Of those in the panel who received a voucher but did not buy any insurance, the majority (4 out of 6 ) indicated lack of understanding of the product as the major reason they did not buy). The other 100 survyed households were outside the original study sample and did not receive any voucher. Of the 120 farmers surveyed, 107 indicated that they received information about the insurance product offered by Nyala. And 94 (out of 105 respondents) indicated that they understood the product well or partially. A very high share (108 out of 120) of farmers among the respondents applied for the Dashen loan covered by weather index insurance. Of the 108 who applied for the loan 105 received the full amount they applied, while the other 3 stated that they received less than what they applied for. The average amount of loan applied for was 1675 birr, with 75 percent of the applicants asking 1400 birr and only 4 applicants asking for 3000 or more birr. Of the 108 farmers who received the loan, 45 knew that the insurance premium was included in the price of the loan. All 108 applicants applied via the local cooperatives and 105 out of the 108 felt that the system of getting bank loans through the cooperatives was appropriate.

We have no counterfactual for the changes measured in Round 5 in Feres Wega, both because this cooperative is clearly endogenously selected in a number of dimensions, and because we did not conduct panel surveys in other villages in this round. We nonetheless conduct an exploratory analysis as to the possible effects of interlinked insurance and credit on input use by simply asking respondents in this village about the changes in their farming behavior that occurred after they received an interlinked loan. Table 11 shows that among those who applied for an interlinked loan, the number reporting increases in chemical fertilizer use (72) far outweigh the numbers who indicate no change (27) or a decline (9). In all input categories the number of those who declared that they increased the use of the relevant input is larger than the number of those indicating a decrease. So while successfully fielding the interlinked product in only one of the intended 40 villages intended underlines the hurdles to implementing these contracts, a surge in input use in FW is consistent with the idea that where we can manage to relax credit and risk constraints simultaneously, input use and productivity will rise. 


\section{CONCLUSION}

Insurance, like credit, is a product that is inherently time inconsistent in the absence of some mechanism to enforce adherence to the contract. The fundamental difference is that credit is time inconsistent for the client, while with insurance it is the firm who wishes to renege. This means that the dynamic credibility of the insurer is a critical precondition for the emergence of market demand. While Ethiopia is known across the world for the severity of its droughts and the huge toll they can take on peasant farmers, it is also an environment in which the state is the ultimate source of credibility. The public sector already plays a central role in absorbing weatherdriven risk, including everything from state guarantees of the agricultural lending system to the massive Productive Safety Nets Program. Given this, private sector actors in the country face an ambiguous legal environment without clear property rights or enforcement of contracts. Thus the context of this study provides a very strong environment in which to test for the impacts of reducing weather risk, but also potentially an uphill climb for private-sector insurance provision.

The effort to shift risk away from smallholder farmers and towards the international reinsurance system is one that appears to present large welfare benefits, but to achieve it through index insurance one must generate wide-scale adoption. Our study illustrates several discouraging points as to the promise of the private sector to deliver this in the Ethiopian context. First, it is clear that the standalone weather index insurance product as promoted and marketed elicited little market demand, and even an individually-targeted promotion conducted at the household level by our survey firm led to no long-term willingness to pay. While the rigidities of the input supply system in the country may be partially to blame, we uncover no path towards a sustainable private market. If it is to be achieved, good marketing \& promotion will be central.

We then show that subsidies providing small free 'tester' insurance policies generated a willingness to accept the contract, but no subsequent improvement in private demand in subsequent seasons even if that insurance policy paid out in the first year. Thus, we find no support for the idea of subsidizing to build the market. Finally, we show that this free insurance did not result in meaningful increases in input investment, suggesting that even the welfare argument for subsidies is absent in this case. Hence, marketing and subsidizing micro-insurance policies all the way down to the level of individual farmers did not relax risk constraints enough to unlock first-order increases in productivity. Our results prove more hope that a properly developed and marketed interlinked product could meet with demand. In the cooperative where 
all of the steps in the chain were forged to provide interlinked insurance to farmers, uptake was strong and more than a hundred farmers were able to access interlinked, private-sector credit.

What is the takeaway message from this study? It is certainly not that risk is unimportant in agriculture; our survey data is full of evidence that this is not the case. A large share of surveyed farmers report risk as the main impediment to purchasing more inputs. However, the standalone WII product, as marketed, was not an effective means to alleviate the risk problem. In some part, this failure is clearly contextual. When public safety net programs are being provided to smallholder farmers at government expense, it is an uphill climb to ask food insecure households to pay from their own pockets for private-sector risk protection. Nonetheless, the results from this study are anything but an outlier; there are literally no examples of developingcountry index insurance pilot programs leaping to scale as market-priced products. So even absent some of the unique institutional obstacles found in Ethiopia, the past few years have seen substantial evidence emerge that private demand from smallholder farmers cannot be the basis for mass-scale adoption of index insurance. In this case, further experimentation with interlinked products may have to forego the possibility of ameliorating risk rationing at the client level, and instead examine the more limited but practical channel of meso-level weather insurance provided directly to financial institutions to help them diversify risk when they lend to agriculture. 


\section{REFERENCES}

Abate, G.T., Rashid, R., Borzaga, C., and Getnet, K. (2015), "Rural finance and agricultural technology adoption in Ethiopia: Does Institutional Design Matter?”, IFPRI Discussion paper 01422

Abrar, S., Morrissey, O., Rayner, T., 2004. Crop Level Supply Response by Agro-Climatic Region in Ethiopia. Journal of Agricultural Economics, 55-2, 289-311.

Alem, Y., Bezabih, M., Kassie, M., Zikhali, P. 2008. Does Fertilizer Use Respond to Rainfall Variability? Panel Data Evidence from Ethiopia. School of Business Economics and Law, University of Gothenburg, Working paper No. 337.

Asfaw, A., Admassie, A., 2004. The role of education on the adoption of chemical fertilizer under different socio-economic environments in Ethiopia. Agricultural Economics 30 (3), 215-228

Abhijit Banerjee, Esther Duflo and Richard Hornbeck, 2014 "Bundling Health Insurance and Microfinance in India: There Cannot Be Adverse Selection If There Is No Demand” American Economic Review 104(5), 291-97

Berhane, G., Dercon, S., Hill, R.V., Seyoum Taffesse, A. (2014) "Formal and informal insurance: experimental evidence from Ethiopia”, IFPRI, processed.

Besley, T. (1995). "Savings, Credit and Insurance”, chapter 36 in Jere Behrman and T.N. Srinivasan (editors) Handbook of Development Economics, vol. 3A, Elsevier, Amsterdam.

Boucher, S.R., Carter, M.R., and Guirkinger, C. 2008, "Risk rationing and wealth effects in credit markets: Theory and implications for agricultural development", American Journal of Agricultural Economics 90(2), pp. 409-423

Bruhn, M., and McKenzie D. (2009), "In pursuit of balance: Randomization in practice in development field experiments” American Economic Journal: Applied Economics, vol. 1, No 4, October, pp. 200-232

Bryan, G., 2010. Ambiguity and insurance, Yale University, Department of Economics

Burke et al., 2010, M., A. de Janvry \& J. Quintero. 2010 Providing index-based agricultural insurance to smallholders: Recent progress and future promise. CEGA, University of California at Berkeley, $38 \mathrm{pp}$.

Cai, J., De Janvry, A., \& Sadoulet, E. (2016). Subsidy policies and insurance demand (No. w22702). National Bureau of Economic Research.

Carter, M. R., Cheng, L., and Sarris, A. (2016), "Where and How Index Insurance Can Boost the Adoption of Improved Agricultural Technologies”, Journal of Development Economics, 118, 5971.

Carter Michael, Alain de Janvry, Elisabeth Sadoulet, and Alexandros Sarris. 2015. “Assurance climatique indicielle pour les pays en développement : Examen des faits et propositions visant à augmenter le taux de souscription.” Revue d'Economie du Développement 23(1): 5-57.

Christiaensen, L., and Demery, L. (2007). Down to Earth: Agriculture and Poverty Reduction in Africa, Directions in Development, World Bank: Washington D.C. 
Clarke, Daniel. 2016. “A Theory of Rational Demand for Index Insurance.” American Economic Journal: Microeconomics, American Economic Association 8(1): 283-306.

Cole, S., Giné X., Tobacman J., Topalova P., Townsend R., and Vickery J. (2013). "Barriers to Household Risk Management: Evidence from India." American Economic Journal: Applied Economics, 5(1): 104-35.

Conning, J. and Udry, C. 2007, "Rural Financial Markets in Developing Countries”, in Handbook of Agricultural Economics. R. Evenson and P. Pingali (Eds), Elsevier. Volume 3: 28572908.

Croppenstedt, A., Demeke, M., Meschi, M., 2003. Technology adoption in the presence of constraints: the case of fertilizer demand in Ethiopia. Review of Development Economics 7-1, $58-70$.

Dadi, L., Burton, M., Ozanne, A., 2004. Duration analysis of technology adoption in Ethiopian agriculture. J. Agric. Econ. 55 (3), 613-631.

Dercon, S. (2005) “Risk, insurance and poverty: A review”. In Stefan Dercon (editor) Insurance Against Poverty, Oxford, Oxford University Press

Dercon, S., R.V. Hill, D. Clarke, I. Outes-Leon and A. Seyoum Taffesse (2014), "Offering rainfall insurance to informal groups: Evidence from a field experiment in Ethiopia”, Journal of Development Economics, 106(2014), 132-143

Dercon, S. and Christiaensen, L. (2011), "Consumption risk, technology adoption and poverty traps: evidence from Ethiopia”, Journal of Development Economics, 96(2), pp. 159-173

Dercon, S., Hill, R. V., 2009. Growth for agriculture in Ethiopia: Identifying key constraints. Paper prepared as part of a study on Agriculture and Growth in Ethiopia.

Dubrovský M 1997 Creating Daily Weather Series with Use of the Weather Generator. Environmetrics 8:409-424.

Dubrovský M, J Buchtele, Z Žalud 2004 High-frequency and low-frequency variability in stochastic daily weather generator and its effect on agricultural and hydrologic modelling. Climatic Change 63:145-179.

Dubrovský M, Z Žalud, M Stastna 2000 Sensitivity of CERES-Maize yields to statistical structure of daily weather series. Climatic Change 46:447-472.

Duru, M.J., 2016. Too Certain to Invest? Public Safety Nets and Insurance Markets in Ethiopia. World Development, 78, pp.37-51.

Duru, M. J. (2016b). The Politics of Economic Risk. University of California, San Diego.

Elabed, Ghada, and Michael Carter. 2015. "Basis Risk and Compound-Risk Aversion: Evidence from a WTP Experiment in Mali.” Journal of Economic Behavior and Organization, vol. 118, Issue $\mathrm{C}$, pp 150-166

Elabed, G., Carter, M. R., (2014). Ex-ante impacts of agricultural insurance: Evidence from a field experiment in Mali. University of California, Davis. Working Paper.

Giné, Xavier, and Dean Yang. 2009. "Insurance, Credit, and Technology Adoption: Field Experiment Evidence from Malawi." Journal of Development Economics 89: 1-11

Hill, Ruth Vargas and Viceisza, Angelino, 2010. "An experiment on the impact of weather shocks 
and insurance on risky investment," IFPRI discussion papers 974, International Food Policy Research Institute (IFPRI)

J-PAL, CEGA, and ATAI Policy Bulletin. 2016. “Make it Rain.” Cambridge, MA: Abdul Latif Jameel Poverty Action Lab, Center for Effective Global Action, and Agricultural Technology Adoption Initiative.

Karlan, Dean, Robert Osei, Isaac Osei-Akoto, and Christopher Udry. 2014. “Agricultural decisions after relaxing credit and risk constraints.” The Quarterly Journal of Economics 129(2): 597-652.

Lamb, R., (2003), "Fertiliser Use, Risk and Off-Farm Labor Markets in the Semi-Arid Tropics of India, American Journal of Agricultural Economics, 85-2: pp. 359-371.

Marenya, P., and Barrett, C., (2009) "State-conditional fertilizer yield response of Western Kenyan farmers”, American Journal of Agricultural Economics, 91(4), pp. 1124-1139

McIntosh, Craig, Felix Povel, and Elisabeth Sadoulet. 2016. "Utility, Risk, and Demand for Incomplete Insurance: Lab Experiments with Guatemalan Cooperatives.” Working paper, University of California at San Diego.

McIntosh, C., Sarris, A., and Papadopoulos F. (2013) "Productivity, Credit, Risk, and the Demand for Weather Index Insurance in Smallholder Agriculture in Ethiopia." Agricultural Economics (44): 399-417.

Mersland, R. and Strøm, R.Ø., 2010. Microfinance mission drift?. World Development, 38(1), pp.28-36.

Mobarak A. M. and M. Rosenzweig, (2013). "Informal Risk Sharing, Index Insurance, and RiskTaking in Developing Countries,” American Economic Review (Papers and Proceedings), 103(3): 375-80, May 2013

Morduch, J., 1999. The role of subsidies in microfinance: evidence from the Grameen Bank. Journal of development economics, 60(1), pp.229-248.

Morris, M., Kelly, V., Kopicki, R., and Byerlee, D., (2007). Fertilizer Use in African Agriculture. Lessons learned and good practice guidelines. Washington DC. World Bank.

OXFAM (2014) "Managing risks to agricultural livelihoods: Impact Evaluation of the HARITA project in Ethiopia (2009-2012)”, February.

Rashid. S., Tefera, N., Minot, N., and Ayele, G. (2013), “Fertilizer in Ethiopia: An assessment of Policies, Value Chain, and Profitability”, IFPRI Discussion paper 01304, December.

Rosenzweig, Mark, and Hans Binswanger. 1993. "Wealth, Weather Risk, and the Composition

Skees J. R., and Collier, B. 2007. "The potential of weather insurance for spurring a green revolution in Africa”. GlobalAgRisk, Inc

Suri, T., (2011) "Selection and comparative advantage in technology adoption”, Econometrica, 79, pp. 159-209.

Townsend, R. M. (1994). Risk and insurance in village India. Econometrica: Journal of the Econometric Society, 539-591.

Yu, B., Nin-Pratt, A., Funes, J., and Asrat Gemessa, S., 2011. Cereal production and technology 
adoption in Ethiopia. International Food Policy Research Institute (IFPRI), Ethiopia Strategy Support Program II (ESSP II), ESSP working paper No 31.

World Bank (2006), National Fertilizer Sector Project: Implementation Completion Repor

Zerfu, D., and Larson, D.F., 2010. Incomplete markets and fertilizer use: Evidence from Ethiopia. World Bank, Development Research Group, Agriculture and Rural Development Team, Policy Research Working Paper No. 5235 
Table 1. EPIICA survey and activity timeline

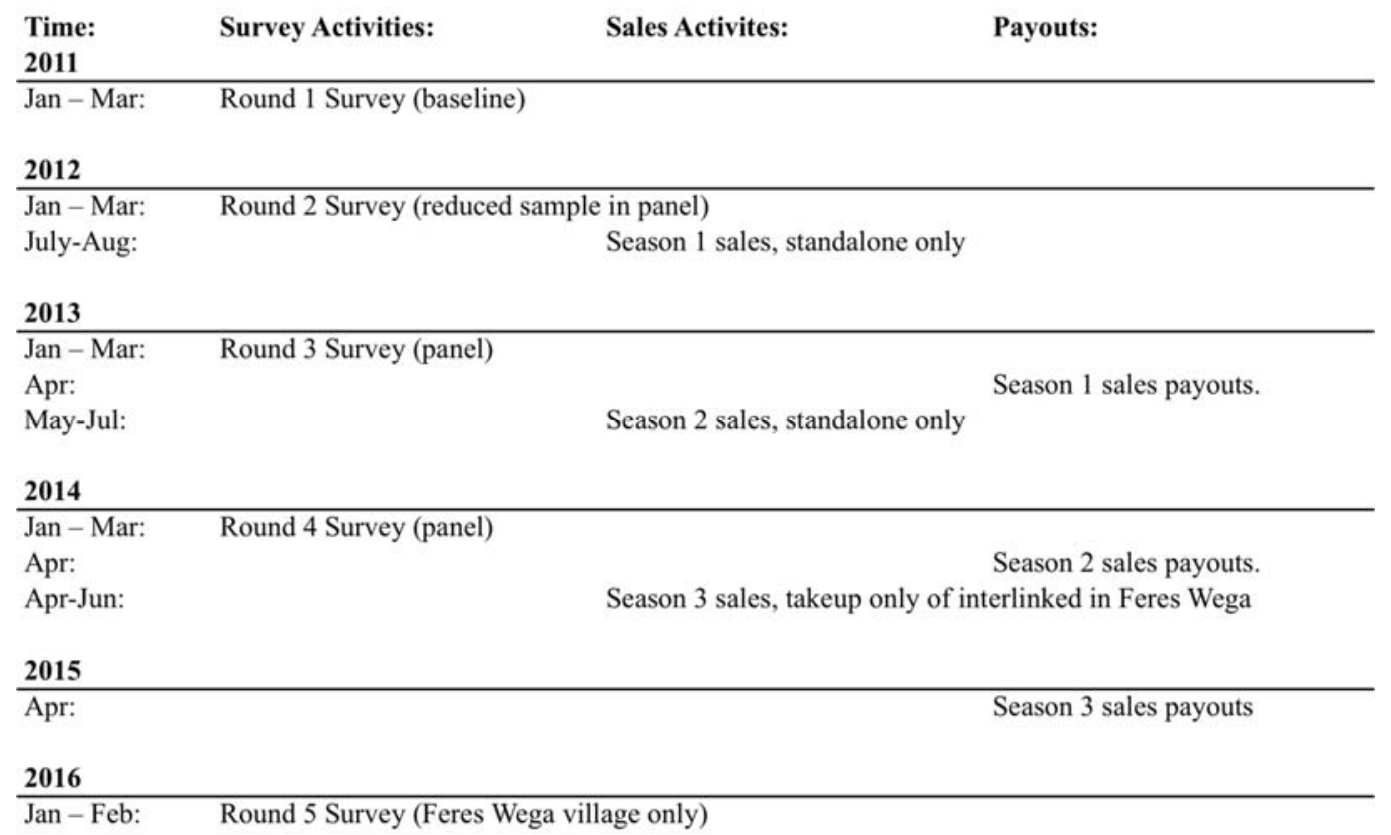


Table 2. Design of the Promotion and Voucher Experiments.

\begin{tabular}{lccc} 
& $\begin{array}{c}\text { Control } \\
(15 \text { villages })\end{array}$ & $\begin{array}{c}\text { Standalone } \\
\text { Arm } \\
\text { (17 villages })\end{array}$ & $\begin{array}{c}\text { Interlinked Arm } \\
\text { (17 villages) }\end{array}$ \\
\cline { 2 - 4 } Initial \# Cooperative Households: & 270 & 306 & 306
\end{tabular}

First Sales Season (outcomes in R3 survey)

Households remaining in panel:

Provided Training \& Promotion

Provided Voucher: None

257

$257 \quad 300$

$300 \quad 291$

0

102

291

257

46

102

100 birr (\$6.94)

49

51

200 birr (\$13.89)

$84 \quad 69$

300 birr (\$20.83)

$\begin{array}{ll}78 & 79\end{array}$

400 birr (\$27.78)

$22 \quad 24$

500 birr (\$34.72)

21

20

Second Sales Season (outcomes in R4 survey)

Households remaining in panel:

Provided Voucher:

None
100 birr (\$6.94)

249

296

249

296

200 birr $(\$ 13.89)$

82

68

74

300 birr (\$20.83)

72

133

51

56

56 
Table 3. Attrition and baseline outcomes

\begin{tabular}{|c|c|c|c|c|c|}
\hline \multirow[b]{2}{*}{ Outcome: } & & & & & \multirow[t]{2}{*}{$\begin{array}{c}\begin{array}{c}\text { Interactions } \\
\text { with } \\
\text { receiving } \\
\text { voucher }\end{array} \\
(5) \\
\end{array}$} \\
\hline & $(1)$ & $(2)$ & $(3)$ & $(4)$ & \\
\hline Interlinked Arm & $\begin{array}{l}-0.0506 \\
(0.110)\end{array}$ & $\begin{array}{l}-0.0541 \\
(0.108)\end{array}$ & $\begin{array}{c}0.0531 \\
(0.0499)\end{array}$ & $\begin{array}{c}0.0564 \\
(0.0493)\end{array}$ & \\
\hline Standalone Arm & $\begin{array}{l}-0.0506 \\
(0.110)\end{array}$ & $\begin{array}{l}-0.0543 \\
(0.107)\end{array}$ & $\begin{array}{c}0.0605 \\
(0.0551)\end{array}$ & $\begin{array}{c}0.0621 \\
(0.0544)\end{array}$ & \\
\hline Ever Received a Voucher & & & $\begin{array}{l}-0.113^{* *} \\
(0.0495)\end{array}$ & $\begin{array}{l}-0.112^{* *} \\
(0.0494)\end{array}$ & \\
\hline HH Size & & $\begin{array}{c}0.0116 \\
(0.0246)\end{array}$ & & $\begin{array}{l}-0.00646 \\
(0.0122)\end{array}$ & $\begin{array}{c}0.0417 \\
(0.0331)\end{array}$ \\
\hline Consumption Aggregate & & $\begin{array}{l}0.00357 \\
(0.0281)\end{array}$ & & $\begin{array}{l}-0.00713 \\
(0.0149)\end{array}$ & $\begin{array}{l}-0.0279 \\
(0.0406)\end{array}$ \\
\hline Hired Farm Labor & & $\begin{array}{c}0.141^{* * *} \\
(0.0486)\end{array}$ & & $\begin{array}{l}0.00591 \\
(0.0156)\end{array}$ & $\begin{array}{c}0.0901 \\
(0.0562)\end{array}$ \\
\hline Age of HH Head & & $\begin{array}{l}0.00246^{*} \\
(0.00145)\end{array}$ & & $\begin{array}{l}-0.000836 \\
(0.000670)\end{array}$ & $\begin{array}{c}0.00435 * * * \\
(0.00144)\end{array}$ \\
\hline Head is Male & & $\begin{array}{l}-0.0301 \\
(0.0504)\end{array}$ & & $\begin{array}{c}0.0655 \\
(0.0425)\end{array}$ & $\begin{array}{c}-0.138 \\
(0.0877)\end{array}$ \\
\hline Marital Status & & $\begin{array}{c}0.0354 \\
(0.0216)\end{array}$ & & $\begin{array}{c}0.0337 \\
(0.0224)\end{array}$ & $\begin{array}{l}-0.0722 \\
(0.0445)\end{array}$ \\
\hline Literacy & & $\begin{array}{l}0.0560^{*} \\
(0.0303)\end{array}$ & & $\begin{array}{c}0.0110 \\
(0.0215)\end{array}$ & $\begin{array}{c}0.0178 \\
(0.0481)\end{array}$ \\
\hline Years of Education & & $\begin{array}{c}0.000227 \\
(0.000391)\end{array}$ & & $\begin{array}{c}3.44 \mathrm{e}-05 \\
(0.000271)\end{array}$ & $\begin{array}{l}-0.000565 \\
(0.000686)\end{array}$ \\
\hline Hours of Hired Labor Used on Farm & & $\begin{array}{l}-0.000231 \\
(0.000521)\end{array}$ & & $\begin{array}{c}3.65 \mathrm{e}-05 \\
(9.30 \mathrm{e}-05)\end{array}$ & $\begin{array}{c}-0.00770^{* *} \\
(0.00381)\end{array}$ \\
\hline Value of Productive Assets & & $\begin{array}{c}-3.93 e-06 \\
(2.84 \mathrm{e}-06)\end{array}$ & & $\begin{array}{c}4.71 \mathrm{e}-07 \\
(6.74 \mathrm{e}-07)\end{array}$ & $\begin{array}{c}8.31 \mathrm{e}-06 \\
(5.23 \mathrm{e}-06)\end{array}$ \\
\hline Value of Consumer Durables & & $\begin{array}{c}-1.77 \mathrm{e}-05^{*} \\
(9.82 \mathrm{e}-06)\end{array}$ & & $\begin{array}{l}-3.27 e-06^{*} \\
(1.90 e-06)\end{array}$ & $\begin{array}{l}1.27 e-05^{*} \\
(7.26 e-06)\end{array}$ \\
\hline Constant & $\begin{array}{c}0.625 * * * \\
(0.0769)\end{array}$ & $\begin{array}{l}0.342 * * \\
(0.141)\end{array}$ & $\begin{array}{c}0.0778^{* * * *} \\
(0.0166)\end{array}$ & $\begin{array}{c}0.0483 \\
(0.0755)\end{array}$ & $\begin{array}{c}0.111 \\
(0.113)\end{array}$ \\
\hline Observations & 2,158 & 2,157 & 882 & 882 & 882 \\
\hline R-squared & 0.002 & 0.031 & 0.027 & 0.048 & 0.086 \\
\hline $\begin{array}{l}\text { F-test: all covariates jointly insignificant } \\
\text { p-value on F-test }\end{array}$ & $\begin{array}{l}0.142 \\
0.868\end{array}$ & $\begin{array}{c}2.963 \\
0.000890\end{array}$ & $\begin{array}{c}4.747 \\
0.00560\end{array}$ & $\begin{array}{c}2.837 \\
0.00364\end{array}$ & $\begin{array}{c}2.373 \\
0.0196\end{array}$ \\
\hline
\end{tabular}


Table 4. Balance test using average pre-treatment outcomes Panel A: Household Characteristics

\begin{tabular}{|c|c|c|c|c|c|c|c|c|c|c|c|}
\hline & $\begin{array}{l}\text { Household } \\
\text { Size }\end{array}$ & $\begin{array}{c}\text { Consumption } \\
\text { Aggregate }\end{array}$ & $\begin{array}{l}\text { Hired Farm } \\
\text { Labor }\end{array}$ & $\begin{array}{c}\text { Age of } \mathrm{HH} \\
\text { Head }\end{array}$ & $\begin{array}{c}\text { Male- } \\
\text { headed } \\
\text { household }\end{array}$ & $\begin{array}{c}\text { Marital } \\
\text { Status of } \\
\text { HH head }\end{array}$ & Literacy & Education & $\begin{array}{l}\text { Household } \\
\text { Hired Labor }\end{array}$ & $\begin{array}{c}\text { Productive } \\
\text { Asset Index }\end{array}$ & $\begin{array}{c}\text { Consumer } \\
\text { Durables }\end{array}$ \\
\hline Interlinked Treatment & $\begin{array}{c}0.466 \\
(0.327)\end{array}$ & $\begin{array}{c}0.398 \\
(0.291)\end{array}$ & $\begin{array}{c}0.0248 \\
(0.0832)\end{array}$ & $\begin{array}{c}1.992 \\
(2.993)\end{array}$ & $\begin{array}{l}-0.0452 \\
(0.0434)\end{array}$ & $\begin{array}{c}0.0372 \\
(0.0693)\end{array}$ & $\begin{array}{l}-0.0291 \\
(0.0707)\end{array}$ & $\begin{array}{l}-3.558 \\
(6.191)\end{array}$ & $\begin{array}{c}3.003 \\
(3.631)\end{array}$ & $\begin{array}{l}-506.3 \\
(526.1)\end{array}$ & $\begin{array}{l}-221.4 \\
(276.0)\end{array}$ \\
\hline Standalone Treatment & $\begin{array}{c}0.291 \\
(0.318)\end{array}$ & $\begin{array}{c}0.336 \\
(0.273)\end{array}$ & $\begin{array}{c}0.0139 \\
(0.0881)\end{array}$ & $\begin{array}{c}3.002 \\
(3.238)\end{array}$ & $\begin{array}{l}-0.0517 \\
(0.0481)\end{array}$ & $\begin{array}{c}0.0990 \\
(0.0822)\end{array}$ & $\begin{array}{l}-0.0435 \\
(0.0717)\end{array}$ & $\begin{array}{l}-4.137 \\
(5.496)\end{array}$ & $\begin{array}{c}8.153 \\
(6.604)\end{array}$ & $\begin{array}{l}-139.7 \\
(413.0)\end{array}$ & $\begin{array}{c}167.3 \\
(359.2)\end{array}$ \\
\hline Voucher S1 & $\begin{array}{l}-0.530^{*} \\
(0.313)\end{array}$ & $\begin{array}{l}-0.355 \\
(0.264)\end{array}$ & $\begin{array}{c}0.0252 \\
(0.0670)\end{array}$ & $\begin{array}{l}-2.187 \\
(2.257)\end{array}$ & $\begin{array}{c}0.0588 \\
(0.0457)\end{array}$ & $\begin{array}{c}-0.136 \\
(0.0851)\end{array}$ & $\begin{array}{l}0.00365 \\
(0.0804)\end{array}$ & $\begin{array}{c}2.241 \\
(4.677)\end{array}$ & $\begin{array}{l}-11.14^{*} \\
(6.087)\end{array}$ & $\begin{array}{l}491.5^{* *} \\
(234.1)\end{array}$ & $\begin{array}{l}-203.1 \\
(213.5)\end{array}$ \\
\hline Voucher Amount S1 & $\begin{array}{l}0.0169 * * \\
(0.00831)\end{array}$ & $\begin{array}{c}0.0114 \\
(0.00734)\end{array}$ & $\begin{array}{l}-0.00140 \\
(0.00258)\end{array}$ & $\begin{array}{l}-0.00505 \\
(0.0775)\end{array}$ & $\begin{array}{l}-0.000323 \\
(0.00136)\end{array}$ & $\begin{array}{l}0.000977 \\
(0.00267)\end{array}$ & $\begin{array}{c}0.00248 \\
(0.00276)\end{array}$ & $\begin{array}{l}0.0539 \\
(0.178)\end{array}$ & $\begin{array}{l}0.434^{*} \\
(0.241)\end{array}$ & $\begin{array}{l}-4.128 \\
(17.30)\end{array}$ & $\begin{array}{c}6.867 \\
(7.257)\end{array}$ \\
\hline Voucher S2 & $\begin{array}{l}0.0491 \\
(0.324)\end{array}$ & $\begin{array}{l}0.0410 \\
(0.281)\end{array}$ & $\begin{array}{c}0.0334 \\
(0.0605)\end{array}$ & $\begin{array}{l}-0.374 \\
(2.270)\end{array}$ & $\begin{array}{l}0.0790^{*} \\
(0.0417)\end{array}$ & $\begin{array}{l}-0.0788 \\
(0.0774)\end{array}$ & $\begin{array}{c}0.116^{*} \\
(0.0673)\end{array}$ & $\begin{array}{c}6.898 \\
(5.985)\end{array}$ & $\begin{array}{c}4.671 \\
(4.341)\end{array}$ & $\begin{array}{l}-1,004 \\
(759.2)\end{array}$ & $\begin{array}{c}11.51 \\
(212.9)\end{array}$ \\
\hline Voucher Amount S2 & $\begin{array}{l}-0.0113 \\
(0.0177)\end{array}$ & $\begin{array}{l}-0.0123 \\
(0.0146)\end{array}$ & $\begin{array}{r}0.000590 \\
(0.00351)\end{array}$ & $\begin{array}{c}0.183^{*} \\
(0.108)\end{array}$ & $\begin{array}{c}-0.00479 * * \\
(0.00229)\end{array}$ & $\begin{array}{c}0.00677 \\
(0.00439)\end{array}$ & $\begin{array}{l}-0.00778 * \\
(0.00439)\end{array}$ & $\begin{array}{l}-0.132 \\
(0.376)\end{array}$ & $\begin{array}{l}-0.0251 \\
(0.294)\end{array}$ & $\begin{array}{c}65.15 \\
(70.00)\end{array}$ & $\begin{array}{l}-4.711 \\
(12.19)\end{array}$ \\
\hline Baseline Outcome in Control & $\begin{array}{c}5.181^{* * *} \\
(0.196) \\
\end{array}$ & $\begin{array}{c}4.335^{* * *} \\
(0.169) \\
\end{array}$ & $\begin{array}{c}0.181^{* * *} \\
(0.0583) \\
\end{array}$ & $\begin{array}{c}48.21^{* * *} \\
(1.875) \\
\end{array}$ & $\begin{array}{l}0.904^{* * *} \\
(0.0163) \\
\end{array}$ & $\begin{array}{c}2.189 * * * \\
(0.0363) \\
\end{array}$ & $\begin{array}{c}0.433^{* * *} \\
(0.0398) \\
\end{array}$ & $\begin{array}{c}-69.80^{* * *} \\
(2.505) \\
\end{array}$ & $\begin{array}{c}2.941^{* * *} \\
(0.991) \\
\end{array}$ & $\begin{array}{c}1,157^{* * *} \\
(357.7) \\
\end{array}$ & $\begin{array}{c}844.6^{* * *} \\
(226.7) \\
\end{array}$ \\
\hline $\begin{array}{l}\text { Observations } \\
\text { R-squared }\end{array}$ & $\begin{array}{c}882 \\
0.008\end{array}$ & $\begin{array}{c}882 \\
0.007\end{array}$ & $\begin{array}{c}882 \\
0.005\end{array}$ & $\begin{array}{c}882 \\
0.014\end{array}$ & $\begin{array}{c}882 \\
0.007\end{array}$ & $\begin{array}{c}882 \\
0.009\end{array}$ & $\begin{array}{c}882 \\
0.005\end{array}$ & $\begin{array}{c}882 \\
0.004\end{array}$ & $\begin{array}{c}882 \\
0.022\end{array}$ & $\begin{array}{c}882 \\
0.003\end{array}$ & $\begin{array}{c}882 \\
0.008\end{array}$ \\
\hline
\end{tabular}

Regressions are household-level OLS analysis among all cooperative members. Regressions examine the balance of Round 1 (pre-treatment) covariates and outcomes by the subsequent village-level treatment and individual-level voucher randomization. Robust standard errors are reported in parentheses, clustered at the village level to account for the design effect. $\quad * * * \mathrm{p}<0.01, * * \mathrm{p}<0.05, * \mathrm{p}<0.1$ 
Table 4 (continued)

Panel B: Primary Outcomes.

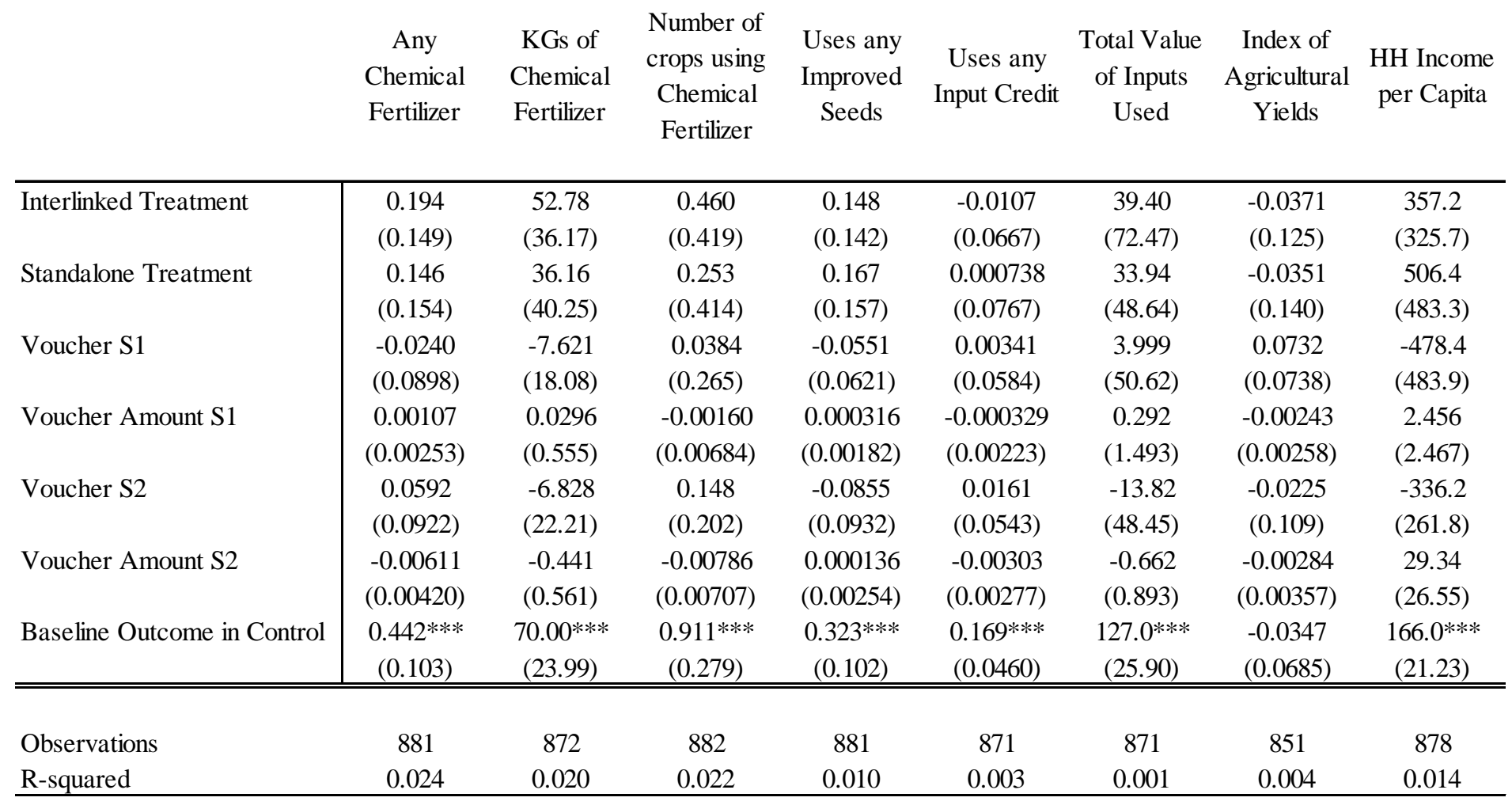

Regressions are household-level OLS analysis among all cooperative members. Regressions examine the balance of Round 1 (pretreatment) covariates and outcomes by the subsequent village-level treatment and individual-level voucher randomization. Robust standard errors are reported in parentheses, clustered at the village level to account for the design effect. $\quad * * * p<0.01, * * p<0.05, * p<0.1$ Source: Computed by authors 
Table 5. Uptake Rates and Sum Insured in the various arms of the study sample:

Round 1:

Uptake Rate:

All

\begin{tabular}{lc} 
Round 2: & All \\
\hline Uptake Rate: & N/A
\end{tabular}

\begin{tabular}{|c|c|c|c|c|c|}
\hline \multirow[b]{2}{*}{ Round 3: } & \multirow[b]{2}{*}{$\begin{array}{c}\text { No } \\
\text { Voucher: }\end{array}$} & \multicolumn{2}{|c|}{ Coop Members: } & \multicolumn{2}{|c|}{ Non-Coop Members: } \\
\hline & & $\begin{array}{l}\text { Standalone } \\
\text { Voucher: }\end{array}$ & $\begin{array}{c}\text { Interlinked } \\
\text { Voucher }\end{array}$ & $\begin{array}{l}\text { Standalone } \\
\text { Voucher: }\end{array}$ & $\begin{array}{c}\text { Interlinked } \\
\text { Voucher }\end{array}$ \\
\hline Uptake Rate: & 0 & $42,9 \%$ & $25,0 \%$ & $29,2 \%$ & $26,1 \%$ \\
\hline Average Sum Insured: & 0 & $\$ 39,91$ & $\$ 35,90$ & $\$ 24,73$ & $\$ 25,28$ \\
\hline Average Own Money Spent: & 0 & $\$ 7,43$ & $\$ 5,41$ & $\$ 4,35$ & $\$ 3,44$ \\
\hline
\end{tabular}

Round 4:

Uptake Rate:

Average Sum Insured:

\begin{tabular}{l|r}
0 & $43,0 \%$ \\
\hline
\end{tabular}

$\$ 37,01$

$43,6 \%$

$\$ 38,49$

$29,4 \%$

$\$ 47,19$

$45,0 \%$

Average Own Money Spent:

$0 \quad \$ 2,22$

$\$ 2,60$

$\$ 11,42$

$\$ 1,02$

Source: EPIICA survey results. 
Table 6. The Impact of Year 1 Vouchers and Payouts on Sales in Year 2

Uptake of Insurance in Year 2

Sum Insured Year 2

\begin{tabular}{|c|c|c|c|c|c|c|}
\hline & & & & & & \\
\hline & (1) & (2) & (3) & (4) & (5) & (6) \\
\hline Any Voucher Year 1 & $\begin{array}{l}0.00683 \\
(0.0220)\end{array}$ & $\begin{array}{c}0.0364 \\
(0.0423)\end{array}$ & $\begin{array}{c}0.0290 \\
(0.0495)\end{array}$ & $\begin{array}{c}18.41 \\
(35.52)\end{array}$ & $\begin{array}{c}80.95 \\
(91.24)\end{array}$ & $\begin{array}{c}33.35 \\
(88.13)\end{array}$ \\
\hline Voucher Amount Year 1 & & $\begin{array}{l}-0.00164 \\
(0.00222)\end{array}$ & $\begin{array}{c}-0.00154 \\
(0.00221)\end{array}$ & & $\begin{array}{l}-3.551 \\
(4.468)\end{array}$ & $\begin{array}{r}-3.218 \\
(4.273)\end{array}$ \\
\hline Any Voucher Year 2 & $\begin{array}{l}0.429 * * * \\
(0.0519)\end{array}$ & $\begin{array}{c}0.419^{* * *} \\
(0.0845)\end{array}$ & $\begin{array}{c}0.406^{* * *} \\
(0.0857)\end{array}$ & $\begin{array}{c}533.5^{* * *} \\
(124.2)\end{array}$ & $\begin{array}{c}129.8 \\
(101.1)\end{array}$ & $\begin{array}{c}109.9 \\
(96.84)\end{array}$ \\
\hline Voucher Amount Year 2 & & $\begin{array}{c}0.000635 \\
(0.00520)\end{array}$ & $\begin{array}{c}0.000867 \\
(0.00521)\end{array}$ & & $\begin{array}{c}28.66^{* * *} \\
(9.146)\end{array}$ & $\begin{array}{c}28.97 * * * \\
(9.252)\end{array}$ \\
\hline Insurance would have paid out Y1 & & & $\begin{array}{c}0.0923 \\
(0.0651)\end{array}$ & & & $\begin{array}{c}120.3 \\
(117.9)\end{array}$ \\
\hline Voucher Y1 * Insurance would pay Y1 & & & $\begin{array}{l}-0.0445 \\
(0.0802)\end{array}$ & & & $\begin{array}{c}23.75 \\
(122.8)\end{array}$ \\
\hline Constant & $\begin{array}{r}-0.00255 \\
(0.00824) \\
\end{array}$ & $\begin{array}{c}-0.00241 \\
(0.00830) \\
\end{array}$ & $\begin{array}{c}-0.0113 \\
(0.00935) \\
\end{array}$ & $\begin{array}{r}-6.865 \\
(13.34) \\
\end{array}$ & $\begin{array}{r}-5.945 \\
(13.18) \\
\end{array}$ & $\begin{array}{r}-17.13 \\
(13.64) \\
\end{array}$ \\
\hline Observations & 841 & 841 & 841 & 841 & 841 & 841 \\
\hline R-squared & 0.296 & 0.297 & 0.301 & 0.150 & 0.175 & 0.182 \\
\hline
\end{tabular}

Source: Computed by authors 
Table 7. Impacts of Receiving Insurance Vouchers on Primary Outcomes.

Panel 7A: Uninteracted Specification.

\begin{tabular}{|c|c|c|c|c|c|c|c|c|c|c|}
\hline & $\begin{array}{l}\text { Covered by } \\
\text { Insurance }\end{array}$ & Sum Insured & $\begin{array}{c}\text { Any } \\
\text { Chemical } \\
\text { Fertilizer }\end{array}$ & $\begin{array}{c}\text { KGs of } \\
\text { Chemical } \\
\text { Fertilizer }\end{array}$ & $\begin{array}{c}\text { Number of } \\
\text { crops using } \\
\text { Chemical } \\
\text { Fertilizer } \\
\end{array}$ & $\begin{array}{l}\text { Uses any } \\
\text { Improved } \\
\text { Seeds }\end{array}$ & $\begin{array}{l}\text { Uses any } \\
\text { Input Credit }\end{array}$ & $\begin{array}{c}\text { Total Value } \\
\text { of Inputs } \\
\text { Used }\end{array}$ & $\begin{array}{l}\text { Index of } \\
\text { Agricultural } \\
\text { Yields }\end{array}$ & $\begin{array}{l}\text { HH Income } \\
\text { per Capita }\end{array}$ \\
\hline & $(1)$ & $(2)$ & (3) & $(4)$ & (5) & $(6)$ & (7) & $(8)$ & (9) & $(10)$ \\
\hline Any Voucher & $\begin{array}{c}0.385 * * * \\
(0.0389)\end{array}$ & $\begin{array}{c}38.81^{* * *} \\
(6.309)\end{array}$ & $\begin{array}{c}0.0203 \\
(0.0381)\end{array}$ & $\begin{array}{l}-1.761 \\
(4.862)\end{array}$ & $\begin{array}{c}-0.0319 \\
(0.0826)\end{array}$ & $\begin{array}{c}0.0607 * \\
(0.0329)\end{array}$ & $\begin{array}{c}0.0127 \\
(0.0339)\end{array}$ & $\begin{array}{c}1.567 \\
(14.31)\end{array}$ & $\begin{array}{l}0.00158 \\
(0.0438)\end{array}$ & $\begin{array}{c}47.79 \\
(55.18)\end{array}$ \\
\hline Treated Village & $\begin{array}{l}-0.00409 \\
(0.0118)\end{array}$ & $\begin{array}{l}-0.780 \\
(1.724)\end{array}$ & $\begin{array}{r}-0.0615 \\
(0.0983)\end{array}$ & $\begin{array}{c}1.153 \\
(6.279)\end{array}$ & $\begin{array}{c}-0.0691 \\
(0.182)\end{array}$ & $\begin{array}{c}-0.124^{*} \\
(0.0689)\end{array}$ & $\begin{array}{c}0.0374 \\
(0.0393)\end{array}$ & $\begin{array}{l}-6.093 \\
(19.63)\end{array}$ & $\begin{array}{r}-0.0848 \\
(0.0932)\end{array}$ & $\begin{array}{c}-190.8^{* *} \\
(89.90)\end{array}$ \\
\hline R3 & $\begin{array}{r}-0.0226 \\
(0.0186)\end{array}$ & $\begin{array}{l}0.0553 \\
(2.815)\end{array}$ & $\begin{array}{c}0.232 * * \\
(0.0920)\end{array}$ & $\begin{array}{c}15.99 * * * \\
(3.735)\end{array}$ & $\begin{array}{c}0.497 * * * \\
(0.176)\end{array}$ & $\begin{array}{c}0.0677 \\
(0.0532)\end{array}$ & $\begin{array}{c}0.0432 \\
(0.0292)\end{array}$ & $\begin{array}{c}3.940 \\
(12.02)\end{array}$ & $\begin{array}{c}-0.0397 \\
(0.0791)\end{array}$ & $\begin{array}{l}101.0 * * \\
(39.62)\end{array}$ \\
\hline R4 & $\begin{array}{c}0.0236 \\
(0.0195)\end{array}$ & $\begin{array}{l}-0.0578 \\
(2.942)\end{array}$ & $\begin{array}{c}0.189 * * \\
(0.0831)\end{array}$ & $\begin{array}{c}17.09 * * * \\
(4.038)\end{array}$ & $\begin{array}{c}0.359 * * \\
(0.150)\end{array}$ & $\begin{array}{c}0.0570 \\
(0.0522)\end{array}$ & $\begin{array}{c}-0.0317 \\
(0.0295)\end{array}$ & $\begin{array}{c}11.35 \\
(16.28)\end{array}$ & $\begin{array}{c}0.0903 \\
(0.0801)\end{array}$ & $\begin{array}{c}137.0 * * * \\
(39.08)\end{array}$ \\
\hline Constant & $\begin{array}{c}0.000123 \\
(0.00991) \\
\end{array}$ & $\begin{array}{l}0.0206 \\
(1.375) \\
\end{array}$ & $\begin{array}{c}0.556 * * * \\
(0.0272) \\
\end{array}$ & $\begin{array}{c}91.02^{* * *} \\
(1.300) \\
\end{array}$ & $\begin{array}{l}1.196^{* * *} \\
(0.0482) \\
\end{array}$ & $\begin{array}{c}0.372^{* * *} \\
(0.0198) \\
\end{array}$ & $\begin{array}{l}0.153^{* * *} \\
(0.00680) \\
\end{array}$ & $\begin{array}{c}128.3^{* * *} \\
(4.802) \\
\end{array}$ & $\begin{array}{c}-0.105^{* * *} \\
(0.0166) \\
\end{array}$ & $\begin{array}{c}246.5^{* * *} \\
(22.91) \\
\end{array}$ \\
\hline Observations & 3,446 & 3,446 & 2,544 & 3,280 & 2,571 & 2,544 & 3,416 & 3,416 & 3,191 & 2,561 \\
\hline Number of Observations & 0.312 & 0.190 & 0.084 & 0.025 & 0.069 & 0.006 & 0.014 & 0.000 & 0.014 & 0.004 \\
\hline
\end{tabular}

Regressions are household fixed-effects analysis among all cooperative members. The first two columns estimate the effect of the intervention on uptake (acceptance of the free insurance voucher). Remaining columns examine impacts on agricultural and household outcomes. Data includes two pre-treatment rounds for some variables and one for others; all variables have two post-treatment observations. Voucher treatment re-randomized at the individual level in rounds 3 and $4 . \quad$ Robust standard errors are reported in parentheses, clustered at the village level to account for the design effect. $* * * \mathrm{p}<0.01, * * \mathrm{p}<0.05, * \mathrm{p}<0.1$ 
Panel 7B: Interacted Specification.

\begin{tabular}{|c|c|c|c|c|c|c|c|c|c|c|}
\hline & $\begin{array}{l}\text { Covered by } \\
\text { Insurance }\end{array}$ & Sum Insured & $\begin{array}{l}\text { Any } \\
\text { Chemical } \\
\text { Fertilizer }\end{array}$ & $\begin{array}{l}\text { KGs of } \\
\text { Chemical } \\
\text { Fertilizer }\end{array}$ & $\begin{array}{c}\text { Number of } \\
\text { crops using } \\
\text { Chemical } \\
\text { Fertilizer } \\
\end{array}$ & $\begin{array}{l}\text { Uses any } \\
\text { Improved } \\
\text { Seeds }\end{array}$ & $\begin{array}{l}\text { Uses any } \\
\text { Input Credit }\end{array}$ & $\begin{array}{c}\text { Total Value } \\
\text { of Inputs } \\
\text { Used }\end{array}$ & $\begin{array}{l}\text { Index of } \\
\text { Agricultural } \\
\text { Yields }\end{array}$ & $\begin{array}{l}\text { HH Income } \\
\text { per Capita }\end{array}$ \\
\hline Any Voucher & $\begin{array}{c}0.362 * * * \\
(0.0856)\end{array}$ & $\begin{array}{c}12.74 \\
(9.075)\end{array}$ & $\begin{array}{c}-0.0771 \\
(0.0499)\end{array}$ & $\begin{array}{l}-3.940 \\
(9.987)\end{array}$ & $\begin{array}{c}-0.240^{*} \\
(0.122)\end{array}$ & $\begin{array}{c}0.129^{* *} \\
(0.0593)\end{array}$ & $\begin{array}{c}0.0896 * \\
(0.0457)\end{array}$ & $\begin{array}{l}-37.07 \\
(35.31)\end{array}$ & $\begin{array}{c}-0.00829 \\
(0.0785)\end{array}$ & $\begin{array}{c}193.2 \\
(160.2)\end{array}$ \\
\hline Interlinked * Voucher & $\begin{array}{l}-0.0653 \\
(0.110)\end{array}$ & $\begin{array}{l}-8.866 \\
(12.78)\end{array}$ & $\begin{array}{l}0.239 * * * \\
(0.0814)\end{array}$ & $\begin{array}{c}4.999 \\
(14.52)\end{array}$ & $\begin{array}{c}0.246 \\
(0.201)\end{array}$ & $\begin{array}{c}-0.162^{* *} \\
(0.0804)\end{array}$ & $\begin{array}{c}-0.0711 \\
(0.0745)\end{array}$ & $\begin{array}{c}70.67 \\
(47.15)\end{array}$ & $\begin{array}{c}-0.0108 \\
(0.0939)\end{array}$ & $\begin{array}{l}-145.3 \\
(167.9)\end{array}$ \\
\hline Voucher Amount & $\begin{array}{c}0.00358 \\
(0.00467)\end{array}$ & $\begin{array}{c}1.568 * * * \\
(0.484)\end{array}$ & $\begin{array}{c}0.00161 \\
(0.00213)\end{array}$ & $\begin{array}{l}-0.103 \\
(0.393)\end{array}$ & $\begin{array}{c}0.0105^{*} \\
(0.00614)\end{array}$ & $\begin{array}{l}-0.00166 \\
(0.00269)\end{array}$ & $\begin{array}{c}-0.00481^{* *} \\
(0.00216)\end{array}$ & $\begin{array}{c}1.195 \\
(1.182)\end{array}$ & $\begin{array}{l}0.000151 \\
(0.00350)\end{array}$ & $\begin{array}{l}-5.004 \\
(3.005)\end{array}$ \\
\hline Interlinked * Voucher Amount & $\begin{array}{c}-0.000478 \\
(0.00631)\end{array}$ & $\begin{array}{c}0.693 \\
(1.000)\end{array}$ & $\begin{array}{c}-0.00690 * * \\
(0.00314)\end{array}$ & $\begin{array}{l}0.0319 \\
(0.646)\end{array}$ & $\begin{array}{c}-0.0117 \\
(0.00828)\end{array}$ & $\begin{array}{c}0.00605 \\
(0.00391)\end{array}$ & $\begin{array}{c}0.00461 \\
(0.00396)\end{array}$ & $\begin{array}{l}-2.093 \\
(1.896)\end{array}$ & $\begin{array}{c}0.00253 \\
(0.00434)\end{array}$ & $\begin{array}{c}1.970 \\
(3.625)\end{array}$ \\
\hline Interlinked Arm & $\begin{array}{c}-0.0168 \\
(0.0140)\end{array}$ & $\begin{array}{l}-2.808 \\
(2.376)\end{array}$ & $\begin{array}{l}-0.102 \\
(0.108)\end{array}$ & $\begin{array}{l}-3.533 \\
(7.395)\end{array}$ & $\begin{array}{l}-0.134 \\
(0.209)\end{array}$ & $\begin{array}{c}-0.0707 \\
(0.0844)\end{array}$ & $\begin{array}{c}0.0478 \\
(0.0514)\end{array}$ & $\begin{array}{l}-13.46 \\
(26.01)\end{array}$ & $\begin{array}{l}-0.0555 \\
(0.107)\end{array}$ & $\begin{array}{c}-134.7^{* *} \\
(65.18)\end{array}$ \\
\hline Standalone Arm & $\begin{array}{l}0.00738 \\
(0.0113)\end{array}$ & $\begin{array}{c}0.559 \\
(1.971)\end{array}$ & $\begin{array}{c}-0.00181 \\
(0.113)\end{array}$ & $\begin{array}{c}7.772 \\
(9.283)\end{array}$ & $\begin{array}{l}0.0127 \\
(0.200)\end{array}$ & $\begin{array}{c}-0.195^{* *} \\
(0.0763)\end{array}$ & $\begin{array}{c}0.0254 \\
(0.0407)\end{array}$ & $\begin{array}{c}4.831 \\
(16.62)\end{array}$ & $\begin{array}{c}-0.125 \\
(0.0967)\end{array}$ & $\begin{array}{l}-264.1 \\
(171.6)\end{array}$ \\
\hline R3 & $\begin{array}{l}-0.0248 \\
(0.0182)\end{array}$ & $\begin{array}{l}-1.765 \\
(2.688)\end{array}$ & $\begin{array}{c}0.233^{* *} \\
(0.0923)\end{array}$ & $\begin{array}{c}16.03 * * * \\
(3.790)\end{array}$ & $\begin{array}{c}0.492 * * * \\
(0.177)\end{array}$ & $\begin{array}{c}0.0669 \\
(0.0533)\end{array}$ & $\begin{array}{c}0.0457 \\
(0.0293)\end{array}$ & $\begin{array}{c}3.389 \\
(11.92)\end{array}$ & $\begin{array}{l}-0.0415 \\
(0.0792)\end{array}$ & $\begin{array}{l}105.7 * * \\
(39.41)\end{array}$ \\
\hline R4 & $\begin{array}{c}0.0259 \\
(0.0191)\end{array}$ & $\begin{array}{c}1.845 \\
(2.810)\end{array}$ & $\begin{array}{l}0.188^{* *} \\
(0.0829)\end{array}$ & $\begin{array}{c}17.05^{* * *} \\
(4.107)\end{array}$ & $\begin{array}{c}0.364^{* *} \\
(0.150)\end{array}$ & $\begin{array}{c}0.0579 \\
(0.0522)\end{array}$ & $\begin{array}{c}-0.0341 \\
(0.0296)\end{array}$ & $\begin{array}{c}11.90 \\
(16.39)\end{array}$ & $\begin{array}{c}0.0923 \\
(0.0802)\end{array}$ & $\begin{array}{c}132.0^{* * *} \\
(38.80)\end{array}$ \\
\hline Constant & $\begin{array}{l}0.000110 \\
(0.00963) \\
\end{array}$ & $\begin{array}{l}0.0163 \\
(1.371) \\
\end{array}$ & $\begin{array}{l}0.556^{* * *} \\
(0.0272) \\
\end{array}$ & $\begin{array}{c}91.03 * * * \\
(1.286) \\
\end{array}$ & $\begin{array}{l}1.196^{* * *} \\
(0.0481) \\
\end{array}$ & $\begin{array}{l}0.372^{* * *} \\
(0.0195) \\
\end{array}$ & $\begin{array}{l}0.153^{* * *} \\
(0.00674) \\
\end{array}$ & $\begin{array}{c}128.3^{* * *} \\
(4.748) \\
\end{array}$ & $\begin{array}{c}-0.105^{* * *} \\
(0.0164) \\
\end{array}$ & $\begin{array}{c}246.5^{* * *} \\
(22.80) \\
\end{array}$ \\
\hline Observations & 3,446 & 3,446 & 2,544 & 3,280 & 2,571 & 2,544 & 3,416 & 3,416 & 3,191 & 2,561 \\
\hline R-Squared & 0.318 & 0.223 & 0.089 & 0.026 & 0.072 & 0.011 & 0.016 & 0.001 & 0.016 & 0.005 \\
\hline Number of Individuals & 882 & 882 & 881 & 880 & 882 & 881 & 882 & 882 & 875 & 881 \\
\hline Baseline Control Mean & 0 & 0 & 0.546 & 91.11 & 1.180 & 0.368 & 0.153 & 147.6 & -0.0698 & 247.6 \\
\hline
\end{tabular}

Regressions are household fixed-effects analysis among all cooperative members. The first two columns estimate the effect of the intervention on uptake (acceptance of the free insurance voucher). Remaining columns examine impacts on agricultural and household outcomes. Data includes two pre-treatment rounds for some variables and one for others; all variables have two post-treatment observations. Voucher treatment re-randomized at the individual level in rounds 3 and $4 . \quad$ Robust standard errors are reported in parentheses,

clustered at the village level to account for the design effect. ${ }^{* * *} \mathrm{p}<0.01,{ }^{* *} \mathrm{p}<0.05,{ }^{*} \mathrm{p}<0.1$

Source: Computed by authors 
Table 8. Impact of the Sum Insured.

Panel 8A: LATE of Sum Insured on Primary Outcomes: Instrumenting Sum Insured with Voucher Amount

\begin{tabular}{|c|c|c|c|c|c|c|c|c|c|}
\hline & $\begin{array}{l}\text { First stage } \\
\quad \text { (Sum } \\
\text { Insured) }\end{array}$ & $\begin{array}{c}\text { Any } \\
\text { Chemical } \\
\text { Fertilizer }\end{array}$ & $\begin{array}{l}\text { KGs of } \\
\text { Chemical } \\
\text { Fertilizer }\end{array}$ & $\begin{array}{c}\text { Number of } \\
\text { crops using } \\
\text { Chemical } \\
\text { Fertilizer } \\
\end{array}$ & $\begin{array}{l}\text { Uses any } \\
\text { Improved } \\
\text { Seeds }\end{array}$ & $\begin{array}{l}\text { Uses any } \\
\text { Input Credit }\end{array}$ & $\begin{array}{c}\text { Total Value } \\
\text { of Inputs } \\
\text { Used }\end{array}$ & $\begin{array}{l}\text { Index of } \\
\text { Agricultural } \\
\text { Yields }\end{array}$ & $\begin{array}{l}\text { HH Income } \\
\text { per Capita }\end{array}$ \\
\hline & (1) & (2) & (3) & (4) & (5) & (6) & (7) & (8) & (9) \\
\hline Sum Insured (instrumented w voucher amt) & & $\begin{array}{c}-0.000389 \\
(0.000551)\end{array}$ & $\begin{array}{c}-0.0171 \\
(0.0938)\end{array}$ & $\begin{array}{c}-0.000310 \\
(0.00127)\end{array}$ & $\begin{array}{c}0.000341 \\
(0.000575)\end{array}$ & $\begin{array}{c}0.000255 \\
(0.000510)\end{array}$ & $\begin{array}{l}0.00106 \\
(0.438)\end{array}$ & $\begin{array}{c}-2.21 \mathrm{e}-05 \\
(0.000781)\end{array}$ & $\begin{array}{l}-1.269 \\
(1.183)\end{array}$ \\
\hline R3 & $\begin{array}{l}-1.062 \\
(2.898)\end{array}$ & $\begin{array}{l}0.210^{* * *} \\
(0.0212)\end{array}$ & $\begin{array}{c}13.29 * * * \\
(3.631)\end{array}$ & $\begin{array}{c}0.437 * * * \\
(0.0485)\end{array}$ & $\begin{array}{c}0.00874 \\
(0.0221)\end{array}$ & $\begin{array}{c}0.0725^{* * * *} \\
(0.0197)\end{array}$ & $\begin{array}{l}-19.87 \\
(16.95)\end{array}$ & $\begin{array}{c}-0.131^{* * *} \\
(0.0309)\end{array}$ & $\begin{array}{c}23.10 \\
(44.54)\end{array}$ \\
\hline R4 & $\begin{array}{c}2.691 \\
(3.561)\end{array}$ & $\begin{array}{c}0.161^{* * *} \\
(0.0196)\end{array}$ & $\begin{array}{c}14.38 * * * \\
(3.400)\end{array}$ & $\begin{array}{l}0.302^{* * *} \\
(0.0451)\end{array}$ & $\begin{array}{c}-0.00844 \\
(0.0204)\end{array}$ & $\begin{array}{l}-0.00337 \\
(0.0181)\end{array}$ & $\begin{array}{l}-12.63 \\
(15.59)\end{array}$ & $\begin{array}{l}-0.00263 \\
(0.0291)\end{array}$ & $\begin{array}{c}45.05 \\
(41.12)\end{array}$ \\
\hline Voucher amount (randomized) & $\begin{array}{c}2.237^{* * *} \\
(0.378)\end{array}$ & & & & & & & & \\
\hline Constant & $\begin{array}{l}0.0416 \\
(1.826) \\
\end{array}$ & $\begin{array}{c}0.556^{* * *} \\
(0.0120) \\
\end{array}$ & $\begin{array}{c}94.76^{* * *} \\
(2.035) \\
\end{array}$ & $\begin{array}{l}1.196^{* * *} \\
(0.0277) \\
\end{array}$ & $\begin{array}{l}0.372^{* * * *} \\
(0.0125) \\
\end{array}$ & $\begin{array}{l}0.153^{* * *} \\
(0.0112) \\
\end{array}$ & $\begin{array}{c}149.2^{* * * *} \\
(9.606) \\
\end{array}$ & $\begin{array}{c}-0.0690^{* * *} \\
(0.0174) \\
\end{array}$ & $\begin{array}{c}246.8^{* * *} \\
(25.29) \\
\end{array}$ \\
\hline Observations & 2,571 & 2,544 & 2,428 & 2,571 & 2,544 & 2,541 & 2,541 & 2,367 & 2,561 \\
\hline Number of households & 882 & 881 & 876 & 882 & 881 & 881 & 881 & 871 & 881 \\
\hline Baseline mean & & 0.546 & 91.11 & 1.180 & 0.368 & 0.153 & 147.6 & -0.0698 & 247.6 \\
\hline
\end{tabular}

Regressions are household fixed-effects instrumental variables analysis among all cooperative members. The first column provides the first stage estimate of voucher amounts on sum insured, and the remaining columns examine the impact of the sum insured, instrumenting for this with the randomized voucher amount. Data includes one pre-treatment rounds and two post-treatment observations. Voucher treatment re-randomized at the individual level in rounds 3 and $4 . \quad$ Robust standard errors are reported in parentheses, clustered at the village level to account for the design effect. $\quad * * * \mathrm{p}<0.01,{ }^{* *} \mathrm{p}<0.05,{ }^{*} \mathrm{p}<0.1$

Source: Computed by authors 
Panel 8B: Impact of the largest voucher amount

\begin{tabular}{|c|c|c|c|c|c|c|c|c|}
\hline & $\begin{array}{c}\text { Any } \\
\text { Chemical } \\
\text { Fertilizer }\end{array}$ & $\begin{array}{l}\text { KGs of } \\
\text { Chemical } \\
\text { Fertilizer }\end{array}$ & $\begin{array}{c}\text { Number of } \\
\text { crops using } \\
\text { Chemical } \\
\text { Fertilizer }\end{array}$ & $\begin{array}{c}\text { Uses any } \\
\text { Improved } \\
\text { Seeds }\end{array}$ & $\begin{array}{l}\text { Uses any } \\
\text { Input Credit }\end{array}$ & $\begin{array}{l}\text { Total Value } \\
\text { of Inputs } \\
\text { Used }\end{array}$ & $\begin{array}{l}\text { Index of } \\
\text { Agricultural } \\
\text { Yields }\end{array}$ & $\begin{array}{l}\text { HH Income } \\
\text { per Capita }\end{array}$ \\
\hline & (2) & (3) & $(4)$ & (5) & (6) & $(7)$ & $(8)$ & $(9)$ \\
\hline Large Voucher $(>\$ 20)$ & $\begin{array}{l}-0.00509 \\
(0.0448)\end{array}$ & $\begin{array}{l}-3.437 \\
(6.083)\end{array}$ & $\begin{array}{c}-0.0292 \\
(0.0955)\end{array}$ & $\begin{array}{c}0.0633 \\
(0.0406)\end{array}$ & $\begin{array}{c}-0.0154 \\
(0.0418)\end{array}$ & $\begin{array}{c}6.309 \\
(12.89)\end{array}$ & $\begin{array}{c}0.0348 \\
(0.0564)\end{array}$ & $\begin{array}{c}1.224 \\
(33.09)\end{array}$ \\
\hline Small Voucher $(0<$ voucher $<\$ 20)$ & $\begin{array}{c}0.0378 \\
(0.0386)\end{array}$ & $\begin{array}{l}-0.648 \\
(5.028)\end{array}$ & $\begin{array}{c}-0.0337 \\
(0.0879)\end{array}$ & $\begin{array}{l}0.0590^{*} \\
(0.0350)\end{array}$ & $\begin{array}{c}0.0318 \\
(0.0325)\end{array}$ & $\begin{array}{l}-1.658 \\
(19.76)\end{array}$ & $\begin{array}{r}-0.0195 \\
(0.0435)\end{array}$ & $\begin{array}{c}79.53 \\
(75.58)\end{array}$ \\
\hline R3 & $\begin{array}{c}-0.0608 \\
(0.0982)\end{array}$ & $\begin{array}{c}1.195 \\
(6.268)\end{array}$ & $\begin{array}{l}-0.0691 \\
(0.182)\end{array}$ & $\begin{array}{l}-0.124^{*} \\
(0.0690)\end{array}$ & $\begin{array}{c}0.0382 \\
(0.0394)\end{array}$ & $\begin{array}{l}-6.217 \\
(19.60)\end{array}$ & $\begin{array}{c}-0.0859 \\
(0.0933)\end{array}$ & $\begin{array}{c}-189.7^{* *} \\
(89.43)\end{array}$ \\
\hline $\mathrm{R} 4$ & $\begin{array}{c}0.234^{* *} \\
(0.0921)\end{array}$ & $\begin{array}{c}16.10^{* * *} \\
(3.763)\end{array}$ & $\begin{array}{c}0.496 * * * \\
(0.177)\end{array}$ & $\begin{array}{c}0.0675 \\
(0.0533)\end{array}$ & $\begin{array}{c}0.0452 \\
(0.0292)\end{array}$ & $\begin{array}{c}3.613 \\
(11.92)\end{array}$ & $\begin{array}{l}-0.0419 \\
(0.0792)\end{array}$ & $\begin{array}{l}104.2 * * \\
(39.29)\end{array}$ \\
\hline Voucher amount (randomized) & $\begin{array}{l}0.187^{* *} \\
(0.0830)\end{array}$ & $\begin{array}{c}16.98^{* * *} \\
(4.072)\end{array}$ & $\begin{array}{l}0.359 * * \\
(0.150)\end{array}$ & $\begin{array}{c}0.0572 \\
(0.0522)\end{array}$ & $\begin{array}{l}-0.0336 \\
(0.0295)\end{array}$ & $\begin{array}{c}11.68 \\
(16.27)\end{array}$ & $\begin{array}{c}0.0927 \\
(0.0801)\end{array}$ & $\begin{array}{c}133.6^{* * *} \\
(38.70)\end{array}$ \\
\hline Constant & $\begin{array}{l}0.556 * * * \\
(0.0272) \\
\end{array}$ & $\begin{array}{c}91.02 * * * \\
(1.300) \\
\end{array}$ & $\begin{array}{l}1.196 * * * \\
(0.0482) \\
\end{array}$ & $\begin{array}{l}0.372 * * * \\
(0.0198) \\
\end{array}$ & $\begin{array}{l}0.153 * * * \\
(0.00678) \\
\end{array}$ & $\begin{array}{c}128.3^{* * *} \\
(4.806) \\
\end{array}$ & $\begin{array}{c}-0.105^{* * *} \\
(0.0166) \\
\end{array}$ & $\begin{array}{c}246.5 * * * \\
(22.86) \\
\end{array}$ \\
\hline Observations & 2,544 & 3,280 & 2,571 & 2,544 & 3,416 & 3,416 & 3,191 & 2,561 \\
\hline R-squared & 0.085 & 0.025 & 0.069 & 0.006 & 0.016 & 0.000 & 0.014 & 0.005 \\
\hline Number of households & 881 & 880 & 882 & 881 & 882 & 882 & 875 & 881 \\
\hline F-test that Large $=$ Small & 1.784 & 0.290 & 0.00330 & 0.0140 & 2.716 & 0.161 & 1.494 & 2.009 \\
\hline $\mathrm{p}$-value on F-test that Large $=$ Small & 0.188 & 0.593 & 0.954 & 0.906 & 0.106 & 0.690 & 0.228 & 0.163 \\
\hline
\end{tabular}

Regressions are household fixed-effects analysis among all cooperative members. Data includes two pre-treatment rounds for some variables and one for others; all variables have two post-treatment observations. Voucher treatment re-randomized at the individual level in rounds 3 and $4 . \quad$ Robust standard errors are reported in parentheses, clustered at the village level to account for the design effect. ${ }^{* * *} \mathrm{p}<0.01,{ }^{* *} \mathrm{p}<0.05,{ }^{*} \mathrm{p}<0.1$

Source: Computed by authors 
Table 9. Heterogeneous Impacts of Vouchers by Baseline Credit Rationing Status

\begin{tabular}{|c|c|c|c|c|c|c|c|c|c|c|}
\hline Panel B: Interacted Specification. & $\begin{array}{l}\text { Covered by } \\
\text { Insurance }\end{array}$ & $\begin{array}{c}\text { Sum } \\
\text { Insured }\end{array}$ & $\begin{array}{c}\text { Any } \\
\text { Chemical } \\
\text { Fertilizer }\end{array}$ & $\begin{array}{l}\text { KGs of } \\
\text { Chemical } \\
\text { Fertilizer }\end{array}$ & $\begin{array}{c}\text { Number of } \\
\text { crops using } \\
\text { Chemical } \\
\text { Fertilizer }\end{array}$ & $\begin{array}{c}\text { Uses any } \\
\text { Improved } \\
\text { Seeds }\end{array}$ & $\begin{array}{l}\text { Uses any } \\
\text { Input Credit }\end{array}$ & $\begin{array}{c}\text { Total Value } \\
\text { of Inputs } \\
\text { Used }\end{array}$ & $\begin{array}{l}\text { Index of } \\
\text { Agricultural } \\
\text { Yields }\end{array}$ & $\begin{array}{l}\text { HH Income } \\
\text { per Capita }\end{array}$ \\
\hline & (1) & (2) & (3) & (4) & (5) & (6) & (7) & (8) & (9) & (10) \\
\hline Any Voucher & $\begin{array}{c}0.367 * * * \\
(0.0363) \\
\end{array}$ & $\begin{array}{c}40.77 * * * \\
(7.113) \\
\end{array}$ & $\begin{array}{c}0.0159 \\
(0.0448) \\
\end{array}$ & $\begin{array}{l}-14.82 \\
(13.45) \\
\end{array}$ & $\begin{array}{r}0.0117 \\
(0.122) \\
\end{array}$ & $\begin{array}{l}-0.0129 \\
(0.0491) \\
\end{array}$ & $\begin{array}{l}0.00422 \\
(0.0368) \\
\end{array}$ & $\begin{array}{l}-3.240 \\
(18.30) \\
\end{array}$ & $\begin{array}{l}-0.0399 \\
(0.0527) \\
\end{array}$ & $\begin{array}{l}-18.40 \\
(29.70) \\
\end{array}$ \\
\hline Any Voucher * Risk Constrained & $\begin{array}{c}0.0680 \\
(0.0564)\end{array}$ & $\begin{array}{c}-7.002 \\
(6.507)\end{array}$ & $\begin{array}{l}0.00778 \\
(0.0566)\end{array}$ & $\begin{array}{c}5.303 \\
(11.39)\end{array}$ & $\begin{array}{l}0.0313 \\
(0.147)\end{array}$ & $\begin{array}{c}0.0647 \\
(0.0559)\end{array}$ & $\begin{array}{c}0.0310 \\
(0.0471)\end{array}$ & $\begin{array}{l}-11.45 \\
(19.05)\end{array}$ & $\begin{array}{c}0.107 \\
(0.0722)\end{array}$ & $\begin{array}{c}-69.93 \\
(51.22)\end{array}$ \\
\hline Any Voucher * Price Constrained & $\begin{array}{c}0.0309 \\
(0.0717)\end{array}$ & $\begin{array}{l}-8.482 \\
(7.238)\end{array}$ & $\begin{array}{c}0.0337 \\
(0.0835)\end{array}$ & $\begin{array}{l}-15.89 \\
(20.43)\end{array}$ & $\begin{array}{l}0.0656 \\
(0.285)\end{array}$ & $\begin{array}{l}0.0237 \\
(0.102)\end{array}$ & $\begin{array}{l}-0.0552 \\
(0.0474)\end{array}$ & $\begin{array}{l}-6.563 \\
(25.68)\end{array}$ & $\begin{array}{l}-0.0621 \\
(0.102)\end{array}$ & $\begin{array}{c}51.81 \\
(63.57)\end{array}$ \\
\hline Any Voucher * Quantity Constrained & $\begin{array}{c}0.0645 \\
(0.0483) \\
\end{array}$ & $\begin{array}{r}-5.501 \\
(6.890) \\
\end{array}$ & $\begin{array}{r}-0.0396 \\
(0.0499) \\
\end{array}$ & $\begin{array}{r}-11.67 \\
(16.07) \\
\end{array}$ & $\begin{array}{l}-0.210 \\
(0.153) \\
\end{array}$ & $\begin{array}{l}-0.0450 \\
(0.0642) \\
\end{array}$ & $\begin{array}{l}-0.0194 \\
(0.0494) \\
\end{array}$ & $\begin{array}{r}-29.86 \\
(23.59) \\
\end{array}$ & $\begin{array}{c}0.0231 \\
(0.0610) \\
\end{array}$ & $\begin{array}{c}38.46 \\
(38.80) \\
\end{array}$ \\
\hline Risk Constrained & $\begin{array}{c}0.000450 \\
(0.000616)\end{array}$ & $\begin{array}{c}-0.000457 \\
(0.0560)\end{array}$ & $\begin{array}{c}-0.125^{* * *} \\
(0.0416)\end{array}$ & $\begin{array}{c}-39.85 * * * \\
(11.54)\end{array}$ & $\begin{array}{c}-0.474 * * * \\
(0.143)\end{array}$ & $\begin{array}{l}-0.112^{* *} \\
(0.0483)\end{array}$ & $\begin{array}{l}-0.0288 \\
(0.0212)\end{array}$ & $\begin{array}{c}-45.97 * * * \\
(16.05)\end{array}$ & $\begin{array}{l}-0.0458 \\
(0.0419)\end{array}$ & $\begin{array}{l}-75.07 \\
(75.79)\end{array}$ \\
\hline Price Constrained & $\begin{array}{c}0.000614 \\
(0.000738)\end{array}$ & $\begin{array}{c}-0.000622 \\
(0.0764)\end{array}$ & $\begin{array}{c}-0.0898 \\
(0.0614)\end{array}$ & $\begin{array}{c}-20.19 \\
(22.87)\end{array}$ & $\begin{array}{c}-0.272 \\
(0.245)\end{array}$ & $\begin{array}{c}-0.111 \\
(0.0798)\end{array}$ & $\begin{array}{l}-0.0105 \\
(0.0314)\end{array}$ & $\begin{array}{c}-48.90 * * \\
(22.39)\end{array}$ & $\begin{array}{c}-0.0372 \\
(0.0636)\end{array}$ & $\begin{array}{l}-102.3 \\
(73.79)\end{array}$ \\
\hline Quantity Constrained & $\begin{array}{c}-0.000107 \\
(0.000366) \\
\end{array}$ & $\begin{array}{r}0.000109 \\
(0.0133) \\
\end{array}$ & $\begin{array}{l}-0.0595 \\
(0.0504) \\
\end{array}$ & $\begin{array}{l}-15.71 \\
(16.62) \\
\end{array}$ & $\begin{array}{c}-0.346^{* *} \\
(0.151) \\
\end{array}$ & $\begin{array}{c}-0.00298 \\
(0.0581) \\
\end{array}$ & $\begin{array}{l}0.00486 \\
(0.0239) \\
\end{array}$ & $\begin{array}{c}-33.01 \\
(20.78) \\
\end{array}$ & $\begin{array}{c}-0.0437 \\
(0.0461) \\
\end{array}$ & $\begin{array}{c}-193.4^{* *} \\
(79.38) \\
\end{array}$ \\
\hline Treated Village & $\begin{array}{c}-0.00920 \\
(0.00765)\end{array}$ & $\begin{array}{l}0.00934 \\
(1.145)\end{array}$ & $\begin{array}{c}0.0900 \\
(0.0848)\end{array}$ & $\begin{array}{c}44.09 \\
(31.95)\end{array}$ & $\begin{array}{c}0.290 \\
(0.295)\end{array}$ & $\begin{array}{c}-0.00695 \\
(0.0941)\end{array}$ & $\begin{array}{c}0.0409 \\
(0.0525)\end{array}$ & $\begin{array}{c}41.49 \\
(30.69)\end{array}$ & $\begin{array}{l}-0.0570 \\
(0.102)\end{array}$ & $\begin{array}{l}-10.55 \\
(82.02)\end{array}$ \\
\hline Round 3 & $\begin{array}{l}-0.0230 \\
(0.0185)\end{array}$ & $\begin{array}{l}0.0233 \\
(2.863)\end{array}$ & $\begin{array}{c}0.149^{*} \\
(0.0757)\end{array}$ & $\begin{array}{l}-1.720 \\
(21.17)\end{array}$ & $\begin{array}{c}0.257 \\
(0.231)\end{array}$ & $\begin{array}{c}0.0319 \\
(0.0578)\end{array}$ & $\begin{array}{c}0.0492 \\
(0.0399)\end{array}$ & $\begin{array}{l}-19.11 \\
(22.66)\end{array}$ & $\begin{array}{l}-0.0427 \\
(0.0852)\end{array}$ & $\begin{array}{c}15.08 \\
(83.62)\end{array}$ \\
\hline Round 4 & $\begin{array}{c}0.0237 \\
(0.0191)\end{array}$ & $\begin{array}{l}-0.0241 \\
(2.955)\end{array}$ & $\begin{array}{c}0.0955 \\
(0.0738)\end{array}$ & $\begin{array}{c}0.700 \\
(22.87)\end{array}$ & $\begin{array}{c}0.122 \\
(0.231)\end{array}$ & $\begin{array}{c}0.0110 \\
(0.0629)\end{array}$ & $\begin{array}{l}-0.0266 \\
(0.0371)\end{array}$ & $\begin{array}{l}-13.90 \\
(25.48)\end{array}$ & $\begin{array}{c}0.0881 \\
(0.0891)\end{array}$ & $\begin{array}{c}37.60 \\
(76.32)\end{array}$ \\
\hline Constant & $\begin{array}{c}-0.000114 \\
(0.000187) \\
\end{array}$ & $\begin{array}{c}0.000116 \\
(0.0142) \\
\end{array}$ & $\begin{array}{l}0.588 * * * \\
(0.0566) \\
\end{array}$ & $\begin{array}{c}100.4^{* * *} \\
(15.72) \\
\end{array}$ & $\begin{array}{c}1.354^{* * *} \\
(0.191) \\
\end{array}$ & $\begin{array}{l}0.399 * * * \\
(0.0574) \\
\end{array}$ & $\begin{array}{l}0.157 * * * \\
(0.0211) \\
\end{array}$ & $\begin{array}{c}145.2^{* * *} \\
(19.79) \\
\end{array}$ & $\begin{array}{c}-0.0892^{* *} \\
(0.0399) \\
\end{array}$ & $\begin{array}{c}303.2 * * * \\
(95.96) \\
\end{array}$ \\
\hline Observations & 3,446 & 3,446 & 2,544 & 3,280 & 2,571 & 2,544 & 3,416 & 3,416 & 3,191 & 2,561 \\
\hline R-Squared & 0.321 & 0.190 & 0.058 & 0.031 & 0.049 & 0.009 & 0.011 & 0.008 & 0.011 & 0.004 \\
\hline Baseline Control Mean & 0 & 0 & 0.546 & 91.11 & 1.180 & 0.368 & 0.153 & 147.6 & -0.0698 & 247.6 \\
\hline
\end{tabular}

Regressions are household-level OLS analysis among all cooperative members. Data includes two pre-treatment rounds for some variables and one for others; all variables have two post-treatment observations. Voucher treatment re-randomized at the individual level in rounds 3 and 4 . Robust standard errors are reported in parentheses,

clustered at the village level to account for the design effect. ${ }^{* * *} \mathrm{p}<0.01,{ }^{* *} \mathrm{p}<0.05, * \mathrm{p}<0.1$

Source: Computed by authors 
Table 10. Impact of the Product Promotion Conducted at Baseline:

First Sales Season

Covered by
Insurance
Second Sales Season

Endline Survey

Knowledge Sum Total Own Any Own Bought Sum Total Own Any Own Knowledge Insured Money Paid Money Paid Insurance Insured Money Paid Money Paid of Product

\begin{tabular}{lcccc|cccccc} 
& $(1)$ & $(2)$ & $(3)$ & $(4)$ & $(5)$ & $(6)$ & $(7)$ & $(8)$ & $(9)$ \\
\hline Received Product Promotion at Baseline & $0.0709^{* *}$ & $194.8^{* * *}$ & $2.810^{* * *}$ & $0.0709^{* *}$ & -0.0295 & -28.27 & $0.852^{*}$ & 0.0107 & -0.00437 \\
& $(0.0344)$ & $(69.49)$ & $(0.720)$ & $(0.0344)$ & $(0.0266)$ & $(33.42)$ & $(0.444)$ & $(0.00652)$ & $(0.0189)$ \\
Any Voucher in Corresponding Season & $0.299^{* * *}$ & $428.8^{* * *}$ & $4.745^{* * *}$ & $0.299^{* * *}$ & $0.442^{* * *}$ & $551.4^{* * *}$ & $2.108^{* *}$ & $0.0416^{* *}$ & -0.0325 \\
& $(0.0595)$ & $(93.30)$ & $(0.923)$ & $(0.0595)$ & $(0.0494)$ & $(127.3)$ & $(0.891)$ & $(0.0157)$ & $(0.0249)$ \\
Constant & $-0.00763^{*}$ & $-20.97^{* *}$ & $-0.303^{* * *}$ & $-0.00763^{*}$ & 0.00954 & 9.135 & $-0.275^{*}$ & -0.00347 & $0.0884^{* *}$ \\
& $(0.00408)$ & $(9.089)$ & $(0.109)$ & $(0.00408)$ & $(0.00874)$ & $(10.88)$ & $(0.154)$ & $(0.00222)$ & $(0.0360)$ \\
\hline \hline & & & & & & & \\
Observations & 847 & 847 & 847 & 847 & 835 & 835 & 835 & 835 & 588 \\
R-squared & 0.183 & 0.121 & 0.162 & 0.183 & 0.296 & 0.150 & 0.015 & 0.027 & 0.004 \\
\hline
\end{tabular}

0.121

0.162

0.183

0.015

0.027

Regressions are household-level OLS analysis among all cooperative members. Data includes two pre-treatment rounds for some variables and one for others; all variables have two post-treatment observations. Columns 1-8 conducted in normal panel structure, Column 9 conducted in the R4-only data that merges in the knowledge survey outcomes. Robust standard errors are reported in parentheses, clustered at the village level to account for the design effect. $* * * \mathrm{p}<0.01, * *$ $\mathrm{p}<0.05, * \mathrm{p}<0.1$

Source: Computed by authors 
Table 11. Reported Changes in Input Use by Feres WEga farmers who took up the interlinked loan:

\begin{tabular}{l|cccc|c}
\multicolumn{1}{l}{} & $\begin{array}{c}\text { Number } \\
\text { Input: }\end{array}$ & $\begin{array}{c}\% \\
\text { Increasing }\end{array}$ & $\begin{array}{c}\text { Number } \\
\text { Increasing }\end{array}$ & $\begin{array}{c}\% \\
\text { Decreasing }\end{array}$ & $\begin{array}{c}\text { Number } \\
\text { with No } \\
\text { Decreasing } \\
\text { Change }\end{array}$ \\
\hline Local Seeds & 20 & $18,5 \%$ & 3 & $2,8 \%$ & 85 \\
Improved Seeds & 28 & $25,9 \%$ & 5 & $4,6 \%$ & 75 \\
Organic Fertilizer & 28 & $25,9 \%$ & 5 & $4,6 \%$ & 75 \\
UREA & 72 & $66,7 \%$ & 9 & $8,3 \%$ & 27 \\
DAP & 70 & $64,8 \%$ & 9 & $8,3 \%$ & 29 \\
Insecticides/Herbicides & 17 & $15,7 \%$ & 2 & $1,9 \%$ & 89 \\
Veterinary Services & 7 & $6,5 \%$ & 0 & $0,0 \%$ & 101 \\
Other Livestock Inputs & 4 & $3,7 \%$ & 1 & $0,9 \%$ & 103 \\
\hline \hline
\end{tabular}

Source: EPIICA Round 5 survey conducted only in the village of Feres Wega where interlinked insurance was successfully sold. 
Figure 1. Map of Rainfall Stations and the Study Area. Figure 1A. EPIICA project area

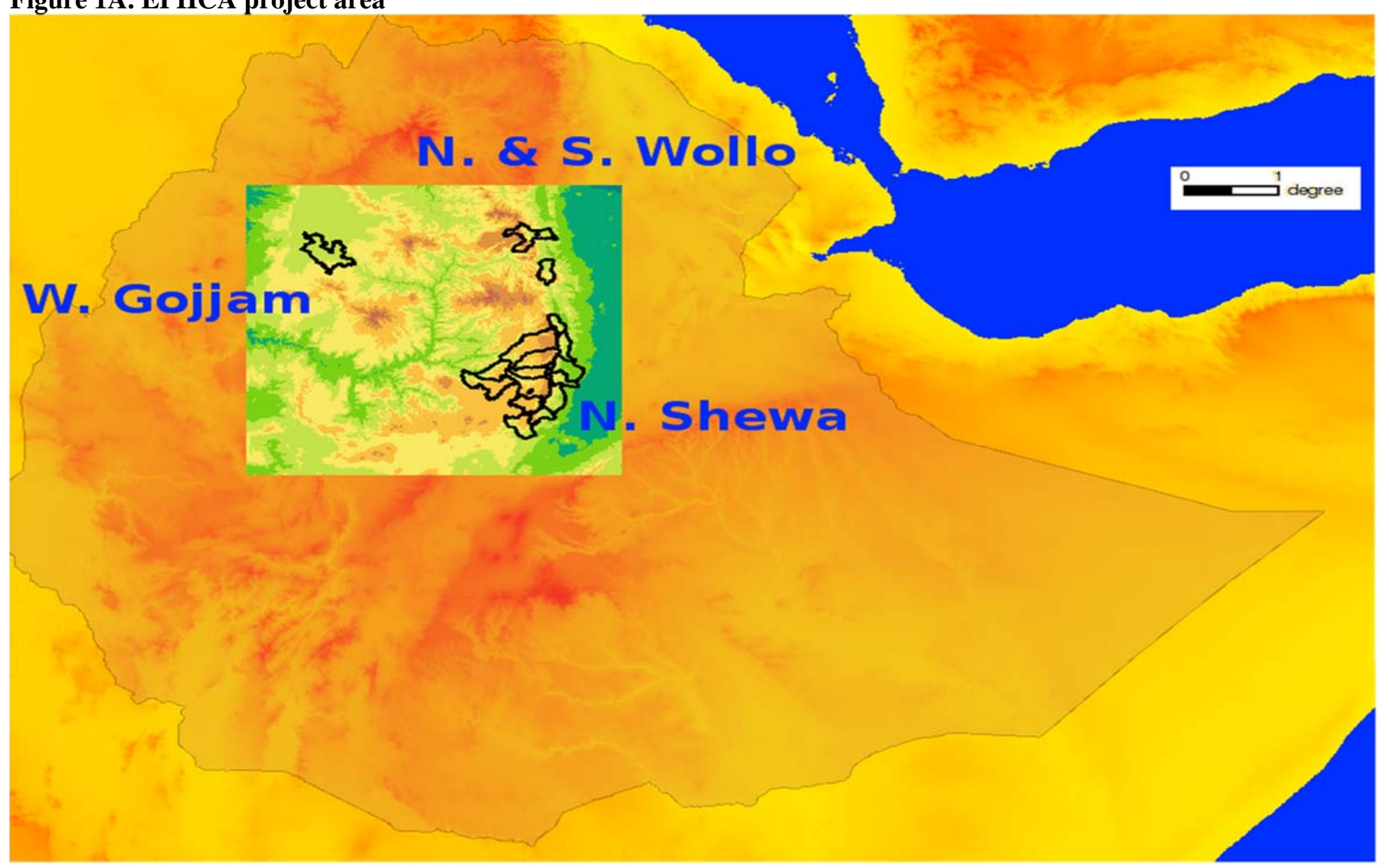


Figure 1B. Map of study woredas (drawn in lines) and rainfall stations (along with their $20 \mathrm{~km}$ perimeter). Red Circles are Study Villages.

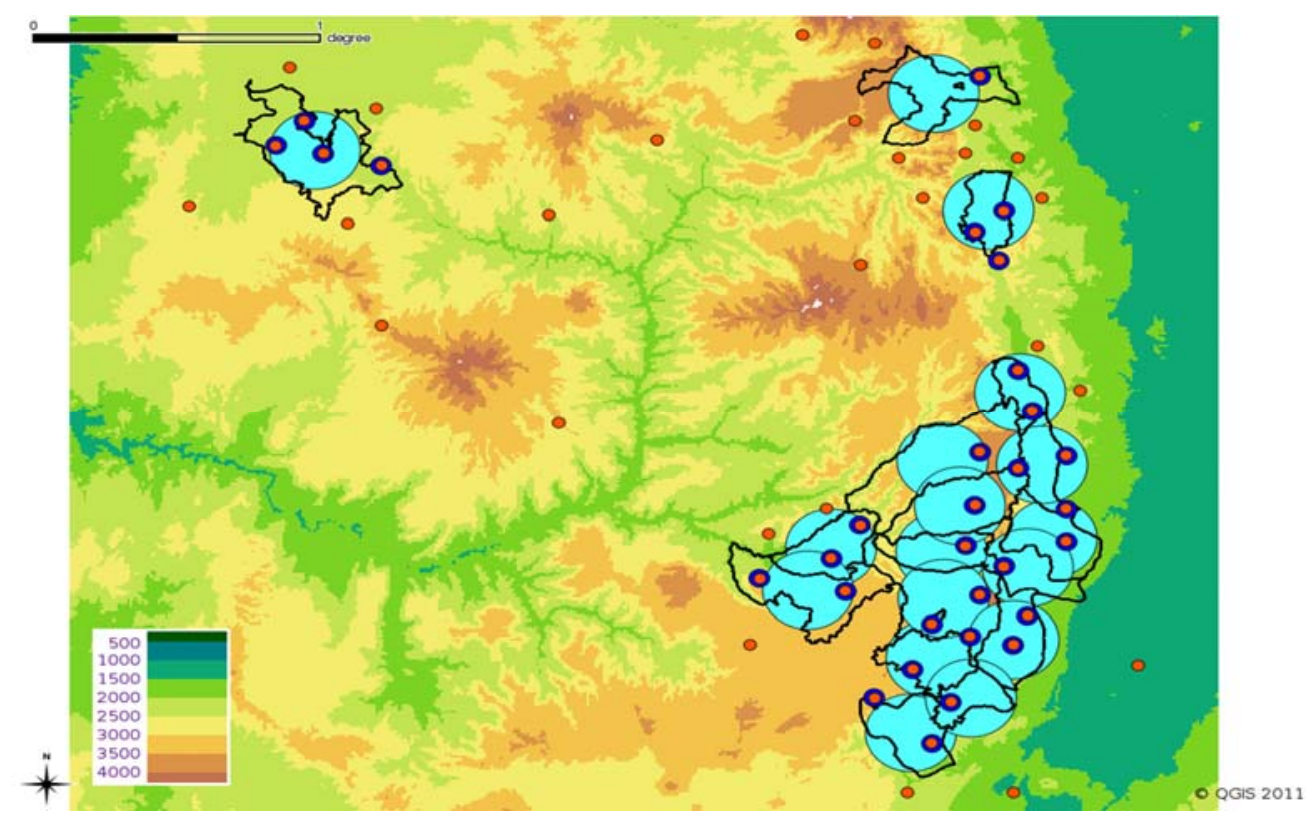

Source. Ethiopian statistical agency and NMA.

Note. The red dots represent study village locations, and the the light blue circles are centered around the rainfall stations. The black lines represent geographical boundaries of woredas (larger administrative regions each including several villages or kebeles) 
Figure 2. CONSORT Diagram of Study Recruitment and Attrition.

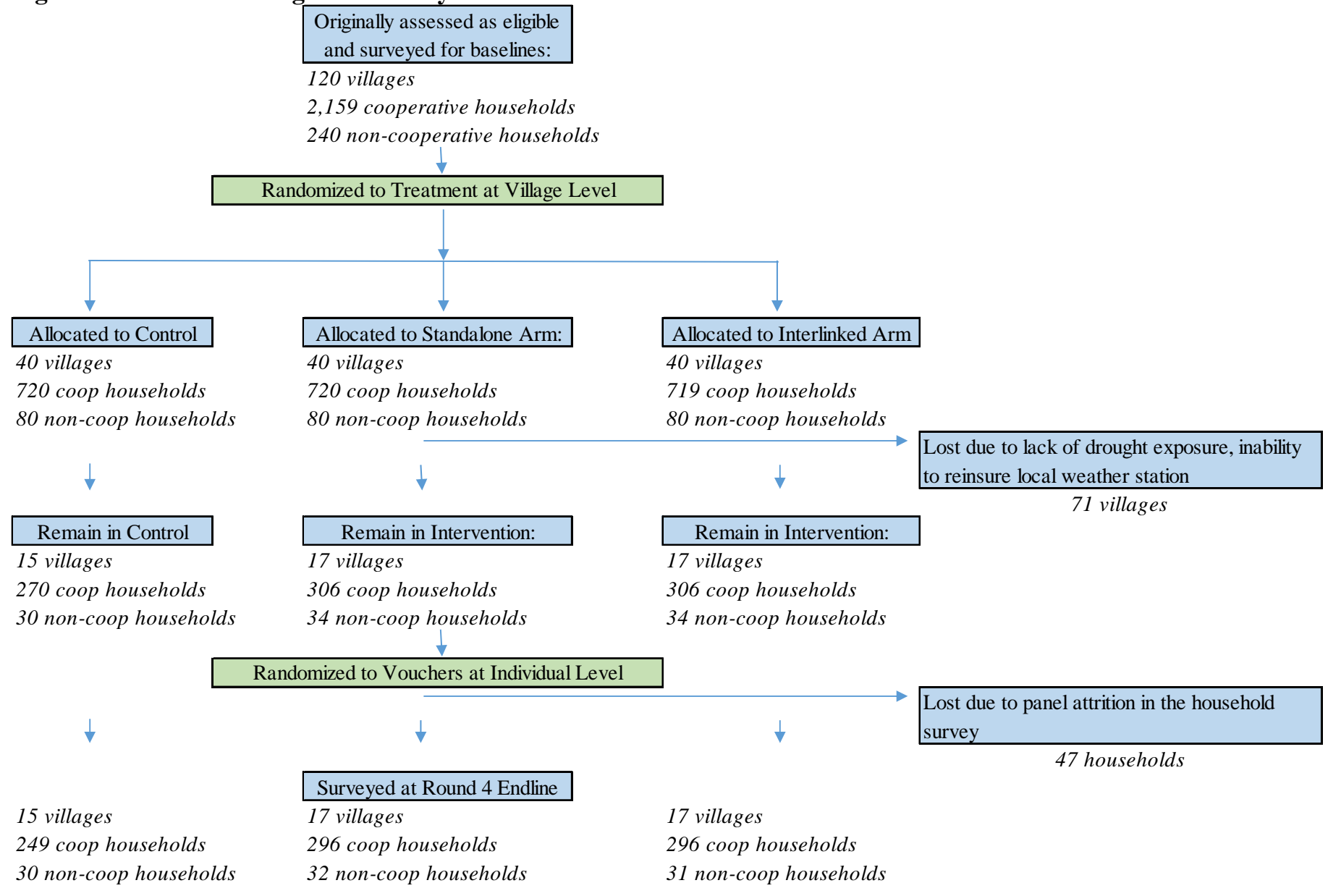


Figure 3. Average Sum Insured by Randomized Voucher Amount.

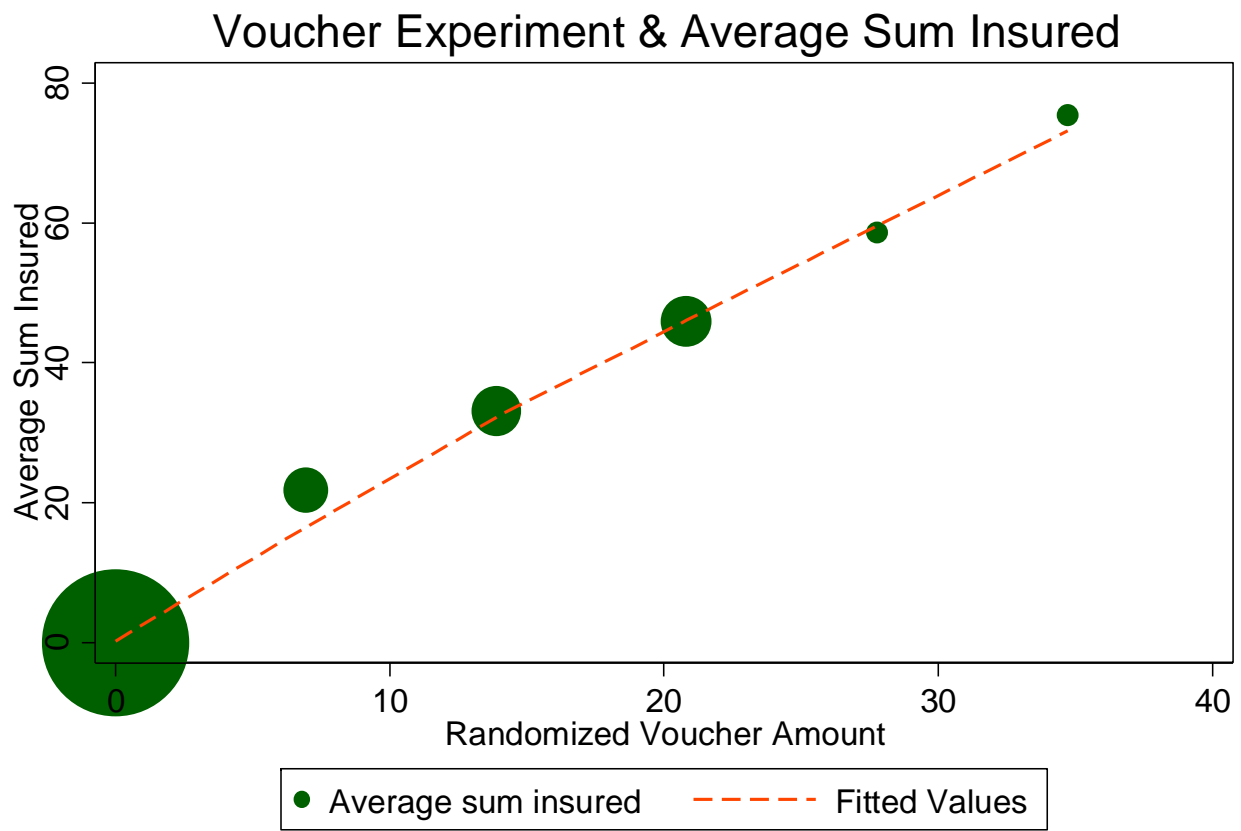

All values in 2010 US\$. Size of dots proportional to number of observations at each assigned value. 
Appendix A. Additional Tables and Figures.

Table A1. Baseline Summary Statistics by Region.

\begin{tabular}{|c|c|c|c|c|c|}
\hline & Total & $\begin{array}{l}\text { North } \\
\text { Shewa }\end{array}$ & $\begin{array}{c}\text { West } \\
\text { Gojam }\end{array}$ & $\begin{array}{l}\text { South } \\
\text { Wollo }\end{array}$ & $\begin{array}{l}\text { North } \\
\text { Wollo }\end{array}$ \\
\hline Number of Households & 1150 & 388 & 363 & 260 & 139 \\
\hline Share of Households in the Zone (\%) & 100 & 100 & 100 & 100 & 100 \\
\hline Average Household Size & 5.3 & 5.5 & 5.8 & 4.6 & 4.99 \\
\hline Number of adult equivalents & 4.5 & 4.7 & 4.8 & 3.9 & 4.23 \\
\hline Average age of the head (years) & 49 & 51.2 & 46.1 & 48.9 & 50.53 \\
\hline \multicolumn{6}{|l|}{ Sex of household head (\%) } \\
\hline Male & 90.7 & 90 & 93.7 & 89.2 & 87.77 \\
\hline Female & 9.3 & 10.1 & 6.3 & 10.8 & 12.23 \\
\hline \multicolumn{6}{|l|}{ Type of hhld head 's education } \\
\hline No Education & 51.4 & 43 & 62 & 46.3 & 56.82 \\
\hline Formal Education & 21.5 & 22.2 & 17.1 & 26.6 & 21.97 \\
\hline Informal Education & 27.1 & 34.8 & 20.9 & 27 & 21.21 \\
\hline $\begin{array}{l}\text { Duration of hhld head's formal education } \\
\text { (years), excluding hh heads with no formal } \\
\text { education at all }\end{array}$ & 4.8 & 5 & 4.5 & 5 & 4.14 \\
\hline \multicolumn{6}{|l|}{ Hhld head can read and write in local language } \\
\hline Read only & 8.2 & 11.6 & 3.6 & 11.2 & 5.04 \\
\hline Read and Write & 35.3 & 34.3 & 32.8 & 38.6 & 38.85 \\
\hline Cannot read or write & 56.5 & 54.1 & 63.6 & 50.2 & 56.12 \\
\hline
\end{tabular}

Source. EPIICA 2011 (R1) Baseline survey 
Table A2. Adequacy of income (percent of households). The years in parentheses refer to the year of realization of the data not the year of the survey

R1 (2010) R3 (2012) R4 (2013)

All All All

Is current household income adequate to meet needs? Not enough even for food Just enough for food 27.2 48.4

20

4.4

20.5

20.5
40.5

27.8

11.3

Source EPIICA R1, R3, R4 surveys.

12.5

43.4

37

7.1 
Table A3. Summary statistics on agricultural activities and household incomes and consumption. The years in parentheses refer to the year of realization of the data not the year of the survey

\begin{tabular}{|c|c|c|c|}
\hline & $\begin{array}{c}\text { Round } 1 \\
(2010)\end{array}$ & $\begin{array}{c}\text { Round } 3 \\
\text { (2012) }\end{array}$ & $\begin{array}{c}\text { Round } 4 \\
\text { (2013) }\end{array}$ \\
\hline Average land owned per hhld (Ha) & 1.47 & 1.24 & 1.18 \\
\hline Average land cultivated in the past 12 months (Ha) & 1.63 & 1.17 & 1.1 \\
\hline Average number of parcels per hhld & 3.68 & 3.51 & 3.49 \\
\hline Percent of area irrigated & 0.12 & 0.14 & 0.11 \\
\hline \multicolumn{4}{|l|}{ Share of Households Using } \\
\hline Chemical Fertilizer & 0.55 & 0.74 & 0.72 \\
\hline Organic Fertilizer & 0.57 & 0.53 & 0.5 \\
\hline Chemicals (pesti/herbicide) & 0.26 & 0.43 & 0.42 \\
\hline Improved seeds & 0.36 & 0.41 & 0.37 \\
\hline \multicolumn{4}{|l|}{ Household Income and Consumption } \\
\hline Total income per eq. adult & 3,169 & 4,186 & 4,526 \\
\hline Total cash income per eq. adult & 2,254 & 3,340 & 3,682 \\
\hline Total noncash income per eq. adult & 915 & 846 & 844 \\
\hline Total consumption per equivalent adult & 2,591 & 2,663 & 2,463 \\
\hline
\end{tabular}

Source. EPIICA R1, R3, and R4 surveys 
Table A4. Replication of Main Impact Table with Attrition Propensity Weights.

\begin{tabular}{|c|c|c|c|c|c|c|c|c|c|c|}
\hline & $\begin{array}{c}\text { Bought } \\
\text { Insurance }\end{array}$ & Sum Insured & $\begin{array}{c}\text { Any Chemical } \\
\text { Fertilizer }\end{array}$ & $\begin{array}{l}\text { KGs of } \\
\text { Chemical } \\
\text { Fertilizer }\end{array}$ & $\begin{array}{c}\text { Number of } \\
\text { crops using } \\
\text { Chemical } \\
\text { Fertilizer }\end{array}$ & $\begin{array}{c}\text { Uses any } \\
\text { Improved } \\
\text { Seeds }\end{array}$ & $\begin{array}{l}\text { Uses any } \\
\text { Input Credit }\end{array}$ & $\begin{array}{l}\text { Total Value of } \\
\text { Inputs Used }\end{array}$ & $\begin{array}{l}\text { Index of } \\
\text { Agricultural } \\
\text { Yields }\end{array}$ & $\begin{array}{c}\text { HH Income } \\
\text { per Capita }\end{array}$ \\
\hline & $(1)$ & $(2)$ & $(3)$ & $(4)$ & $(5)$ & $(6)$ & $(7)$ & $(8)$ & $(9)$ & $(10)$ \\
\hline Any Voucher & $\begin{array}{l}0.385^{* * *} \\
(0.0387)\end{array}$ & $\begin{array}{c}38.74 * * * \\
(6.249)\end{array}$ & $\begin{array}{c}0.0208 \\
(0.0385)\end{array}$ & $\begin{array}{l}-1.688 \\
(4.863)\end{array}$ & $\begin{array}{l}-0.0237 \\
(0.0830)\end{array}$ & $\begin{array}{l}0.0620^{*} \\
(0.0334)\end{array}$ & $\begin{array}{c}0.0133 \\
(0.0335)\end{array}$ & $\begin{array}{c}1.791 \\
(14.62)\end{array}$ & $\begin{array}{l}0.00124 \\
(0.0446)\end{array}$ & $\begin{array}{c}43.68 \\
(54.00)\end{array}$ \\
\hline Treated Village & $\begin{array}{l}-0.00393 \\
(0.0114)\end{array}$ & $\begin{array}{l}-0.761 \\
(1.668)\end{array}$ & $\begin{array}{l}-0.0620 \\
(0.0989)\end{array}$ & $\begin{array}{c}0.857 \\
(6.224)\end{array}$ & $\begin{array}{l}-0.0789 \\
(0.182)\end{array}$ & $\begin{array}{l}-0.124 * \\
(0.0694)\end{array}$ & $\begin{array}{c}0.0390 \\
(0.0384)\end{array}$ & $\begin{array}{l}-7.394 \\
(19.48)\end{array}$ & $\begin{array}{l}-0.0833 \\
(0.0956)\end{array}$ & $\begin{array}{c}-188.7 * * \\
(89.28)\end{array}$ \\
\hline R3 & $\begin{array}{l}-0.0219 \\
(0.0181)\end{array}$ & $\begin{array}{l}0.0520 \\
(2.721)\end{array}$ & $\begin{array}{l}0.232^{* *} \\
(0.0929)\end{array}$ & $\begin{array}{c}16.07 * * * \\
(3.690)\end{array}$ & $\begin{array}{c}0.496 * * * \\
(0.175)\end{array}$ & $\begin{array}{c}0.0658 \\
(0.0538)\end{array}$ & $\begin{array}{c}0.0409 \\
(0.0282)\end{array}$ & $\begin{array}{c}4.305 \\
(11.74)\end{array}$ & $\begin{array}{l}-0.0400 \\
(0.0813)\end{array}$ & $\begin{array}{l}103.7^{* *} \\
(41.74)\end{array}$ \\
\hline R4 & $\begin{array}{c}0.0231 \\
(0.0191)\end{array}$ & $\begin{array}{l}-0.0549 \\
(2.873)\end{array}$ & $\begin{array}{c}0.188 * * \\
(0.0834)\end{array}$ & $\begin{array}{c}17.08^{* * *} \\
(4.048)\end{array}$ & $\begin{array}{c}0.360 * * \\
(0.150)\end{array}$ & $\begin{array}{c}0.0551 \\
(0.0526)\end{array}$ & $\begin{array}{l}-0.0341 \\
(0.0287)\end{array}$ & $\begin{array}{c}11.86 \\
(16.20)\end{array}$ & $\begin{array}{c}0.0896 \\
(0.0822)\end{array}$ & $\begin{array}{c}137.8^{* * *} \\
(39.17)\end{array}$ \\
\hline Constant & $\begin{array}{l}0.000114 \\
(0.00963) \\
\end{array}$ & $\begin{array}{l}0.0198 \\
(1.333) \\
\end{array}$ & $\begin{array}{c}0.553^{* * *} \\
(0.0274) \\
\end{array}$ & $\begin{array}{c}90.16^{* * * *} \\
(1.264) \\
\end{array}$ & $\begin{array}{l}1.188^{* * * *} \\
(0.0484) \\
\end{array}$ & $\begin{array}{c}0.371^{* * *} \\
(0.0197) \\
\end{array}$ & $\begin{array}{l}0.153^{* * *} \\
(0.00669) \\
\end{array}$ & $\begin{array}{c}127.4^{* * *} \\
(4.761) \\
\end{array}$ & $\begin{array}{c}-0.105^{* * *} \\
(0.0170)\end{array}$ & $\begin{array}{c}245.3^{* * * *} \\
(22.82)\end{array}$ \\
\hline $\begin{array}{l}\text { Observations } \\
\text { Number of Observations }\end{array}$ & $\begin{array}{l}3,446 \\
0.312\end{array}$ & $\begin{array}{l}3,446 \\
0.190\end{array}$ & $\begin{array}{l}2,544 \\
0.084\end{array}$ & $\begin{array}{l}3,280 \\
0.025\end{array}$ & $\begin{array}{l}2,571 \\
0.069\end{array}$ & $\begin{array}{l}2,544 \\
0.006\end{array}$ & $\begin{array}{l}3,416 \\
0.014\end{array}$ & $\begin{array}{l}3,416 \\
0.000\end{array}$ & $\begin{array}{l}3,191 \\
0.013\end{array}$ & $\begin{array}{l}2,561 \\
0.004\end{array}$ \\
\hline
\end{tabular}

Regressions are household fixed-effects analysis among all cooperative members, analysis weighted with inverse propensity weights to account for the observable determinants of attrition. The first two columns estimate the effect of the intervention on uptake (acceptance of the free insurance voucher). Remaining columns examine impacts on agricultural and household outcomes. Data includes two pre-treatment rounds for some variables and one for others; all variables have two post-treatment observations. Voucher treatment rerandomized at the individual level in rounds 3 and 4 . Robust standard errors are reported in parentheses, clustered at the village level to account for the design effect. $* * * \mathrm{p}<0.01$, ** $\mathrm{p}<0.05, * \mathrm{p}<0.1$

Source. Computed by authors 
Table A5. Heterogeneity in Impacts for Non-Cooperative Members.

Differential effect on non-coop members

\begin{tabular}{|c|c|c|c|c|c|c|c|c|c|c|}
\hline & $\begin{array}{c}\text { Bought } \\
\text { Insurance }\end{array}$ & Sum Insured & $\begin{array}{c}\text { Any Chemical } \\
\text { Fertilizer }\end{array}$ & $\begin{array}{c}\text { KGs of } \\
\text { Chemical } \\
\text { Fertilizer }\end{array}$ & $\begin{array}{c}\text { Number of } \\
\text { crops using } \\
\text { Chemical } \\
\text { Fertilizer } \\
\end{array}$ & $\begin{array}{l}\text { Uses any } \\
\text { Improved } \\
\text { Seeds }\end{array}$ & $\begin{array}{l}\text { Uses any } \\
\text { Input Credit }\end{array}$ & $\begin{array}{c}\text { Total Value of } \\
\text { Inputs Used }\end{array}$ & $\begin{array}{c}\text { Index of } \\
\text { Agricultural } \\
\text { Yields }\end{array}$ & $\begin{array}{r}\text { HH Income } \\
\text { per Capita }\end{array}$ \\
\hline & $(1)$ & $(2)$ & $(3)$ & $(4)$ & $(5)$ & $(6)$ & $(7)$ & $(8)$ & $(9)$ & $(10)$ \\
\hline Any Voucher * Non Coop Member & $\begin{array}{l}-0.0603 \\
(0.0523)\end{array}$ & $\begin{array}{l}-2.179 \\
(7.338)\end{array}$ & $\begin{array}{l}-0.0445 \\
(0.0580)\end{array}$ & $\begin{array}{l}-0.0105 \\
(11.99)\end{array}$ & $\begin{array}{l}0.00941 \\
(0.164)\end{array}$ & $\begin{array}{l}-0.0462 \\
(0.0642)\end{array}$ & $\begin{array}{l}-0.0536 \\
(0.0433)\end{array}$ & $\begin{array}{l}-0.985 \\
(12.72)\end{array}$ & $\begin{array}{c}0.101 \\
(0.0699)\end{array}$ & $\begin{array}{c}90.82 \\
(108.8)\end{array}$ \\
\hline Any Voucher & $\begin{array}{l}0.393 * * * \\
(0.0385)\end{array}$ & $\begin{array}{c}38.07 * * * \\
(5.799)\end{array}$ & $\begin{array}{l}0.00988 \\
(0.0393)\end{array}$ & $\begin{array}{l}-14.37 \\
(11.84)\end{array}$ & $\begin{array}{l}-0.0289 \\
(0.108)\end{array}$ & $\begin{array}{l}-0.0102 \\
(0.0428)\end{array}$ & $\begin{array}{l}0.00140 \\
(0.0321)\end{array}$ & $\begin{array}{l}-11.24 \\
(13.08)\end{array}$ & $\begin{array}{l}-0.0289 \\
(0.0466)\end{array}$ & $\begin{array}{l}-28.55 \\
(26.10)\end{array}$ \\
\hline Not Coop Member & $\begin{array}{c}0.000232 \\
(0.000487)\end{array}$ & $\begin{array}{l}0.00472 \\
(0.0325)\end{array}$ & $\begin{array}{c}-0.0917 * * \\
(0.0414)\end{array}$ & $\begin{array}{c}-29.07 * * * \\
(9.245)\end{array}$ & $\begin{array}{c}-0.309 * * * \\
(0.111)\end{array}$ & $\begin{array}{l}-0.0536 \\
(0.0380)\end{array}$ & $\begin{array}{c}0.0241 \\
(0.0252)\end{array}$ & $\begin{array}{c}-37.72 * * * \\
(12.05)\end{array}$ & $\begin{array}{l}-0.0519 \\
(0.0332)\end{array}$ & $\begin{array}{c}10.56 \\
(66.04)\end{array}$ \\
\hline Treated Village & $\begin{array}{l}-0.00881 \\
(0.00710)\end{array}$ & $\begin{array}{l}-0.179 \\
(1.073)\end{array}$ & $\begin{array}{c}0.0875 \\
(0.0862)\end{array}$ & $\begin{array}{c}39.96 \\
(30.89)\end{array}$ & $\begin{array}{c}0.308 \\
(0.288)\end{array}$ & $\begin{array}{l}-0.0133 \\
(0.0908)\end{array}$ & $\begin{array}{c}0.0454 \\
(0.0521)\end{array}$ & $\begin{array}{c}39.53 \\
(28.97)\end{array}$ & $\begin{array}{l}-0.0461 \\
(0.0998)\end{array}$ & $\begin{array}{l}-16.75 \\
(78.93)\end{array}$ \\
\hline R3 & $\begin{array}{c}-0.0234 \\
(0.0185)\end{array}$ & $\begin{array}{l}-0.476 \\
(2.861)\end{array}$ & $\begin{array}{l}0.159^{* *} \\
(0.0758)\end{array}$ & $\begin{array}{c}0.261 \\
(20.47)\end{array}$ & $\begin{array}{c}0.264 \\
(0.225)\end{array}$ & $\begin{array}{c}0.0475 \\
(0.0564)\end{array}$ & $\begin{array}{c}0.0439 \\
(0.0374)\end{array}$ & $\begin{array}{l}-16.72 \\
(21.69)\end{array}$ & $\begin{array}{l}-0.0422 \\
(0.0841)\end{array}$ & $\begin{array}{c}42.18 \\
(73.40)\end{array}$ \\
\hline R4 & $\begin{array}{c}0.0239 \\
(0.0189)\end{array}$ & $\begin{array}{c}0.486 \\
(2.922)\end{array}$ & $\begin{array}{c}0.107 \\
(0.0748)\end{array}$ & $\begin{array}{c}2.584 \\
(21.81)\end{array}$ & $\begin{array}{c}0.126 \\
(0.225)\end{array}$ & $\begin{array}{c}0.0299 \\
(0.0615)\end{array}$ & $\begin{array}{l}-0.0280 \\
(0.0353)\end{array}$ & $\begin{array}{l}-11.64 \\
(24.07)\end{array}$ & $\begin{array}{c}0.0847 \\
(0.0881)\end{array}$ & $\begin{array}{c}52.02 \\
(70.37)\end{array}$ \\
\hline Constant & $\begin{array}{r}-2.28 \mathrm{e}-05 \\
(4.80 \mathrm{e}-05) \\
\end{array}$ & $\begin{array}{r}-0.000465 \\
(0.00321) \\
\end{array}$ & $\begin{array}{c}0.541^{* * *} \\
(0.0543) \\
\end{array}$ & $\begin{array}{c}88.34^{* * *} \\
(14.18) \\
\end{array}$ & $\begin{array}{c}1.175^{* * *} \\
(0.165) \\
\end{array}$ & $\begin{array}{c}0.361^{* * *} \\
(0.0522) \\
\end{array}$ & $\begin{array}{c}0.152^{* * *} \\
(0.0184) \\
\end{array}$ & $\begin{array}{c}126.6^{* * *} \\
(15.54) \\
\end{array}$ & $\begin{array}{c}-0.109 * * * \\
(0.0340) \\
\end{array}$ & $\begin{array}{c}239.5^{* * *} \\
(63.40) \\
\end{array}$ \\
\hline Observations & 3,822 & 3,822 & 2,822 & 3,621 & 2,853 & 2,822 & 3,788 & 3,788 & 3,524 & 2,841 \\
\hline R-squared & 0.315 & 0.186 & 0.051 & 0.019 & 0.031 & 0.003 & 0.009 & 0.003 & 0.008 & 0.000 \\
\hline Baseline Control mean & 0 & 0 & 0.546 & 91.11 & 1.180 & 0.368 & 0.153 & 147.6 & -0.0698 & 247.6 \\
\hline
\end{tabular}

Regressions present pooled OLS analysis among all survey respondents. The first two columns estimate the effect of the intervention on uptake (acceptance of the free insurance voucher).

Remaining columns examine impacts on agricultural and household outcomes. Data includes two pre-treatment rounds for some variables and one for others; all variables have two posttreatment observations. Voucher treatment re-randomized at the individual level in rounds 3 and 4 . Robust standard errors are reported in parentheses, clustered at the village level to account for the design effect. $\quad * * * p<0.01,{ }^{* *} \mathrm{p}<0.05$, ${ }^{*} \mathrm{p}<0.1$

Source. Computed by authors 
Figure A1: Rainfall probability density (assumed to be normally distributed) showing Entry and Exit values.

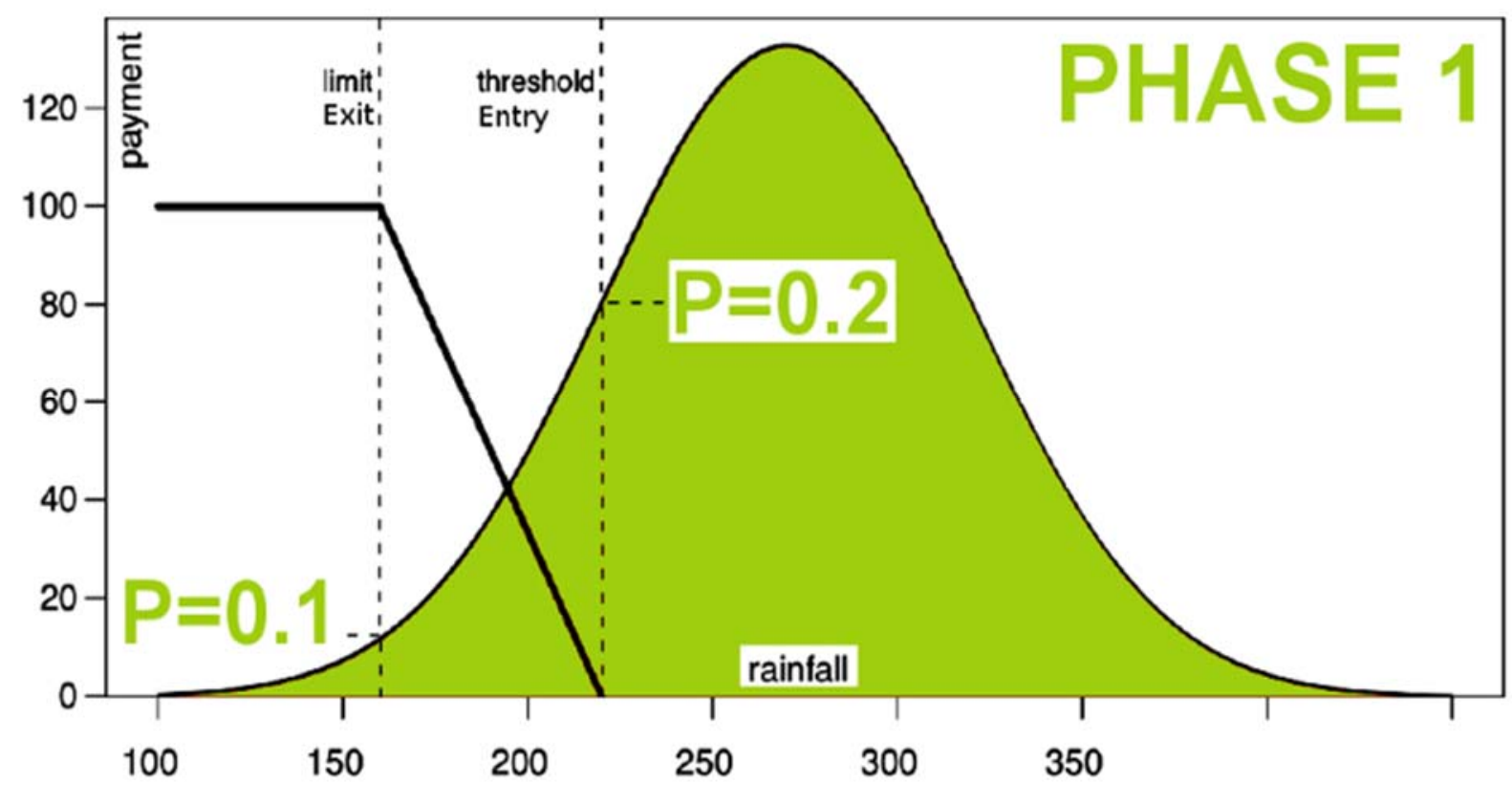

Source: Modified from Burke et al, 2010. 